\title{
Inhibitory effect of 4-O-methylhonokiol on lipopolysaccharide-induced neuroinflammation, amyloidogenesis and memory impairment via inhibition of nuclear factor-kappaB in vitro and in vivo models
}

Young-Jung Lee ${ }^{1,2}$, Dong-Young Choi ${ }^{1,2}$, Im Seop Choi ${ }^{1,2}$, Ki Ho Kim³ ${ }^{3}$ Young Hee Kim³, Hwan Mook Kim ${ }^{4}$ Kiho Lee ${ }^{4}$, Won Gil Cho ${ }^{5}$, Jea Kyung Jung ${ }^{1,2}$, Sang Bae Han ${ }^{1,2}$, Jin-Yi Han ${ }^{1}$, Sang-Yoon Nam ${ }^{6}$, Young Won Yun ${ }^{6}$, Jae Hwang Jeong ${ }^{7}$, Ki-Wan Oh ${ }^{1,2}$ and Jin Tae Hong ${ }^{1,2^{*}}$

\begin{abstract}
Background: Neuroinflammation is important in the pathogenesis and progression of Alzheimer disease (AD). Previously, we demonstrated that lipopolysaccharide (LPS)-induced neuroinflammation caused memory impairments. In the present study, we investigated the possible preventive effects of 4-O-methylhonokiol, a constituent of Magnolia officinalis, on memory deficiency caused by LPS, along with the underlying mechanisms.

Methods: We investigated whether 4-O-methylhonokiol $(0.5$ and $1 \mathrm{mg} / \mathrm{kg}$ in $0.05 \%$ ethanol) prevents memory dysfunction and amyloidogenesis on AD model mice by intraperitoneal LPS (250 $\mathrm{mg} / \mathrm{kg}$ daily 7 times) injection. In addition, LPS-treated cultured astrocytes and microglial BV-2 cells were investigated for anti-neuroinflammatory and anti-amyloidogenic effect of 4-O-methylhonkiol (0.5, 1 and $2 \mu \mathrm{M})$.
\end{abstract}

Results: Oral administration of 4-O-methylhonokiol ameliorated LPS-induced memory impairment in a dosedependent manner. In addition, 4-O-methylhonokiol prevented the LPS-induced expression of inflammatory proteins; inducible nitric oxide synthase (iNOS) and cyclooxygenase-2 (COX-2) as well as activation of astrocytes (expression of glial fibrillary acidic protein; GFAP) in the brain. In in vitro study, we also found that 4-Omethylhonokiol suppressed the expression of iNOS and COX-2 as well as the production of reactive oxygen species, nitric oxide, prostaglandin $E_{2}$, tumor necrosis factor- $\alpha$, and interleukin- $1 \beta$ in the LPS-stimulated cultured astrocytes. 4-O-methylhonokiol also inhibited transcriptional and DNA binding activity of NF- $\kappa \mathrm{B}$ via inhibition of $\mid \kappa \mathrm{B}$ degradation as well as p50 and p65 translocation into nucleus of the brain and cultured astrocytes. Consistent with the inhibitory effect on neuroinflammation, 4-O-methylhonokiol inhibited LPS-induced A $\beta_{1-42}$ generation, $\beta$ - and $\gamma$ secretase activities, and expression of amyloid precursor protein (APP), BACE1 and C99 as well as activation of astrocytes and neuronal cell death in the brain, in cultured astrocytes and in microglial BV-2 cells.

Conclusion: These results suggest that 4-O-methylhonokiol inhibits LPS-induced amyloidogenesis via antiinflammatory mechanisms. Thus, 4-O-methylhonokiol can be a useful agent against neuroinflammation-associated development or the progression of AD.

Keywords: Alzheimer's disease, Amyloid, Lipopolysaccharide, Neuroinflammation, 4-O-methylhonokiol, Magnolia officinalis, Memory impairment

\footnotetext{
* Correspondence: jinthong@chungbuk.ac.kr

${ }^{1}$ College of Pharmacy, Chungbuk National University, 12, Gaeshin-dong,

Heungduk-gu, Cheongju, Chungbuk 361-763, Korea

Full list of author information is available at the end of the article
} 


\section{Background}

Alzheimer's disease (AD) is the most common cause of dementia accounting for $50 \%$ to $75 \%$ of all cases $[1,2]$. $\mathrm{AD}$ is pathologically characterized by the presence of senile plaques and neurofibrillary tangles in the brain. In particular, the senile plaques are extracellular aggregates of the amyloid beta-peptide $(A \beta)$ that is cleaved from the amyloid precursor protein (APP) [3]. Neuropathological studies in the human brains have demonstrated that the activation of glial cells excessively releases proinflammatory mediators and cytokines, which in turn trigger a neurodegenerative cascades via neuroinflammation [4-8]. Numerous investigators have reported that neuroinflammatory processes contribute to the pathogenesis and progression of AD. In neuroinflammation, various cytokines, chemokines, oxygen free radicals, and reactive nitrogen species [9], as well as prostaglandin $E_{2}$ $\left(\mathrm{PGE}_{2}\right)$ [10], are important signaling molecules and components of neuroinflammatory responses [11].

It has also been shown that the inflammatory mediators such as Nitric oxide (NO) and prostaglandins (PGs) as well as cytokines such as interleukin (IL)-1, IL-6, tumor necrosis factor- $\alpha$ (TNF- $\alpha$ ) and transforming growth factor $-\beta$ (TGF- $\beta$ ) can augment APP expression $[12,13]$ and $A \beta$ formation [14]. These inflammatory mediators and cytokines are able to transcriptionally upregulate $\beta$-secretase mRNA, protein, and enzymatic activity [15], thus affecting $A \beta$ formation [16]. However, anti-inflammatory compounds decrease memory deficiency and the accumulation of $A \beta$ plaques, and elevate levels of soluble APP- $\alpha[17,18]$. Moreover, the administration of anti-inflammatory agents in AD patients could reduce amyloidogenesis, suggesting that neuroinflammation may influence the occurrence and pathogenesis of AD through anti-amyloidogenesis [19].

Systemic administration of lipopolysaccharides (LPS) induces cognitive impairment in mice $[20,21]$. The administration of LPS also induces the release of the proinflammatory cytokines such as IL-1 $1 \beta$, IL- 6 , and TNF- $\alpha$ and these cytokines exert neurobiological effects [22], suggesting that induction of systemic inflammation affects the neurobiological condition. There is much evidence illustrating that LPS-induced neuroinflammation is related to the up-regulation of NF- $\kappa \mathrm{B}$ [23-26]. LPSinduced neuronal damages can be restored via the inhibition of $\mathrm{I} \kappa \mathrm{B}$ kinase- $\beta$ [23]. In our previous study, we showed that intraperitoneal (i.p.) injections of LPS induced memory impairment and amyloidogenesis in in vivo, and anti-inflammatory compounds such as (-)-epigallocatechin-3-gallate (EGCG) abolished LPS-induced amyloidogenesis via inhibiting NF- $\kappa \mathrm{B}$ as well as inhibiting $\beta$ - and $\gamma$-secretase activities $[27,28]$. Thus, systemic administration of LPS could be applicable for the study of neuroinflammation and neuroinflammation-associated pathogenesis of $\mathrm{AD}$.

Magnolia bark has been used in traditional medicine to treat various disorders [29,30]. Several constituents of the Magnolia such as honokiol, obovatol and magnolol have been reported to have anti-inflammatory [31-33], neuroprotective [34-36], and anti-oxidative effects $[37,38]$. Recently, we found that 4-O-methylhonokiol isolated from Magnolia officinalis has anti-oxidative [39], anti-inflammatory [40] and neurotrophic activities [41]. It also showed memory-improving effects via the reduction of $A \beta$ accumulation in $A \beta_{1-42}$-injected mice and memory-deficient transgenic mice via the anti-oxidative and anti-inflammatory effects [42-44]. In this study, to define the effect of 4-O-methylhonokiol against $\mathrm{A} \beta$ accumulation via the prevention of neuroinflammation, we investigated the effect of 4-O-methylhonokiol on LPS-induced memory impairments and amyloidogenesis via anti-inflammatory reactions in LPS-injected mice brain, in cultured astrocytes and in microglial BV-2 cells.

\section{Methods}

\section{4-O-methylhonokiol}

2-[4-Methoxy-3-(2-propenyl)phenyl]-4-(2-propenyl)phenol (4-O-methylhonokiol, Molecular Weight $=280.4$, Molecular Formula $=\mathrm{C}_{19} \mathrm{H}_{20} \mathrm{O}_{2}$ ) of chemical structure shown in Figure 1A was isolated from the bark of Magnolia officinalis as described elsewhere $[40,45]$. The bark of Magnolia officinalis was dried in the shade at room temperature and stored in a dark, cold room until use. The air-dried bark of Magnolia officinalis (3 kg) was cut into pieces and extracted twice with $95 \%(\mathrm{v} / \mathrm{v})$ ethanol (four times as much as the weight of the dried plants) for 3 days at room temperature. After filtration through the 400-mesh filter cloth, the filtrate was re-filtered through filter paper (Whatman, No. 5) and concentrated under reduced pressure. The extract $(450 \mathrm{~g})$ was then suspended in distilled water, and the aqueous suspension was extracted with n-hexane, ethyl acetate, and nbutanol, respectively. The $\mathrm{n}$-hexane layer was evaporated to dry, and the residue $(70 \mathrm{~g})$ was chromatographed on silica gel with $n$-hexane:ethyl acetate (9:1) solution to extract a crude fraction that included 4-O-methylhonokiol. This fraction was repeatedly purified by silica gel chromatography using n-hexane:ethyl acetate as the eluent to obtain pure 4-O-methylhonokiol (Figure 1A). The purity was more than 99.5\%. 4-O-methylhonokiol was identified by $1 \mathrm{H}$ NMR $(400 \mathrm{MHz}, \mathrm{CDCl} 3)$ I: $3.36(2 \mathrm{H}$, d, J $=7 \mathrm{~Hz}, \mathrm{H}-7), 3.44\left(2 \mathrm{H}, \mathrm{d}, \mathrm{J}=7 \mathrm{~Hz}, 7^{\prime}-\mathrm{H}\right), 3.89(3 \mathrm{H}$, s, OMe), 5.05-5.14 (5H, m, H-9, H-9', OH), 5.93-6.07 $\left(2 \mathrm{H}, \mathrm{m}, \mathrm{H}-8, \mathrm{H}-8^{\prime}\right), 6.92(1 \mathrm{H}, \mathrm{d}, \mathrm{J}=7 \mathrm{~Hz}, \mathrm{Ar}-\mathrm{H}), 6.97$ $(1 \mathrm{H}, \mathrm{d}, \mathrm{J}=8 \mathrm{~Hz}, \mathrm{Ar}-\mathrm{H}), 7.04-7.08(2 \mathrm{H}, \mathrm{m}, \mathrm{Ar}-\mathrm{H}), 7.24-$ 


\section{A}<smiles>C=CCc1ccc(O)c(-c2ccc(OC)c(CC=C)c2)c1</smiles>

B

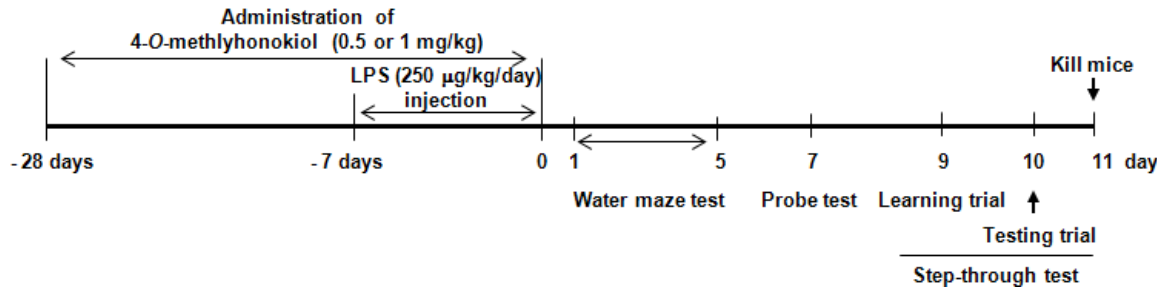

Figure 1 Chemical structure of 4-O-methylhonokiol (A) and experimental scheme (B).

$7.31(2 \mathrm{H}, \mathrm{m}, \mathrm{Ar}-\mathrm{H})$ and $13 \mathrm{C} \mathrm{NMR} \mathrm{(100} \mathrm{MHz,} \mathrm{CDCl3)}$ I: 34.5 (C-7), 39.6 (C-7'), 55.8 (OMe), 111.2 (C-3'), 115.7 (C-4'), 115.8 (C-9), $116.1\left(\mathrm{C}-9^{\prime}\right), 128.0\left(\mathrm{C}-1^{\prime}\right), 128.1(\mathrm{C}-$ 6), 129.0 (C-3), 129.2 (C-1), 130.0 (C-5), 130.4 (C-6'), 130.7 (C-2), 132.4 (C-5'), 136.7 (C-8), 138.0 (C-8'), 151.0 (C-2'), 157.2 (C-4). The ethanol extract of Magnolia officinalis contained 16.6\% 4-O-methylhonokiol followed by $16.5 \%$ honokiol and $12.9 \%$ magnolol, and $42-45 \%$ others. The information of 4-O-methylhonokiol was previously reported $[40,45]$. The result was in agreement with previously published data $[46,47]$, and this compound may possibly be the same compound demonstrated by Zhou et al. [35].

Dosage $(0.5$ and $1 \mathrm{mg} / \mathrm{kg} /$ day $)$ of 4-O-methylhonokiol in this study was used by referring to our previous studies [43-45,48]. 4-O-methylhonokiol (15 and $30 \mu \mathrm{g} /$ mouse) was added to drinking water ( $5 \mathrm{ml}$ of average water consumption of mouse per day) and mice were allowed access for 3 weeks ad libitum before induction of memory impairment as shown in Figure 1B.

\section{Lipopolysaccharide-induced memory impairment mouse model}

Five week-old male imprinting control region (ICR) mice (Samtako, Gyeonggi-do, Korea) were maintained in accordance with the Institutional Animal Care and Use Committee (IACUC) of Laboratory Animal Research Center at Chungbuk National University, Korea (CBNUA-144-1001-01). All mice were housed in a room that was automatically maintained at $21-25^{\circ} \mathrm{C}$ and relative humidity (45-65\%) with a controlled light-dark cycle. Several researchers reported that repeated i.p. injection of LPS induced cognitive impairment like AD in mice [21,49-51]. We therefore used this method as an AD mice model. The LPS (Sigma, St. Louis, MO. USA, final concentration of $0.1 \mathrm{mg} / \mathrm{ml}$ ) was dissolved, and aliquots in saline were stored at $-20^{\circ} \mathrm{C}$ until use. The i.p. injection $(250 \mu \mathrm{g} / \mathrm{kg})$ of LPS or control (saline) was daily administered for 7 days. Subsequently, the behavioral tests of learning and memory capacity were assessed using two separate tests (water maze and passive avoidance test). One day interval was given between tests for adaptation of new circumstances as shown in Figure 1B.

\section{Water maze test}

The water maze test is also a widely accepted method for memory test, and we performed this test as described by Morris et al. [52]. Maze testing was performed by the SMART-CS (Panlab, Barcelona, Spain) program and equipment. A circular plastic pool (height: $35 \mathrm{~cm}$, diameter: $100 \mathrm{~cm}$ ) was filled with milky water kept at $22-25^{\circ} \mathrm{C}$. An escape platform (height: $14.5 \mathrm{~cm}$, diameter: $4.5 \mathrm{~cm}$ ) was submerged $0.5-1 \mathrm{~cm}$ below the surface of the water in position. On training trials, the mice were placed in a pool of water and allowed to remain on the platform for $10 \mathrm{~s}$ and were then returned to the home cage during the second-trial interval. The mice that did not find the platform within $60 \mathrm{~s}$ were placed on the platform for $10 \mathrm{~s}$ at the end of trial. They were allowed to swim until they sought the escape 
platform. These trials were performed in single platform and in three starting positions of rotational starting. Escape latency, escape distance, swimming speed and swimming pattern of each mouse was monitored by a camera above the center of the pool connected to a SMART-LD program (Panlab, Barcelona, Spain).

\section{Probe test}

A probe trial in order to assess memory consolidation was performed $24 \mathrm{~h}$ after the 5 -day acquisition tests. In this trial, the platform was removed from the tank, and the mice were allowed to swim freely. For these tests, the percentage time in the target quadrant and target site crossings within $60 \mathrm{~s}$ was recorded. The time spent in the target quadrant is taken to indicate the degree of memory consolidation that has taken place after learning. The time spent in the target quadrant was used as a measure of spatial memory. Swimming pattern of each mouse was monitored by a camera above the center of the pool connected to a SMART-LD program described above.

\section{Passive avoidance performance test}

The passive avoidance test is widely accepted as a simple and rapid method for memory test. The passive avoidance response was determined using a "stepthrough" apparatus (Med Associates Inc, Vermont, USA) that is consisted of an illuminated and a dark compartment (each $20.3 \times 15.9 \times 21.3 \mathrm{~cm}$ ) adjoining each other through a small gate with a grid floor, 3.175 $\mathrm{mm}$ stainless steel rod set $8 \mathrm{~mm}$ apart. Two days after the water maze test, the ICR mice were placed in the illuminated compartment facing away from the dark compartment for the training trial. When the mice moved completely into the dark compartment, it received an electric shock ( $2 \mathrm{~mA}, 3 \mathrm{~s}$ duration). Then the mice were returned to their home case. $24 \mathrm{~h}$ later, the mice were placed in the illuminated compartment and the latency period to enter the dark compartment defined as "retention" was measured. The time when the mice entered in the dark compartment was recorded and described as step-through latency. The retention trials were set at a limit of $180 \mathrm{~s}$ of cutoff time.

\section{Astrocytes and microglial BV-2 cells culture}

As described elsewhere [53,54], 2-day-olds rat pups were ice-anesthetized and decapitated. After the skull was cut and the skin was opened, the brain was released from the skull cavity. After washing with PBS, the cerebrum was separated from the cerebellum and brain stem, and the cerebral hemispheres were separated from each other by gently teasing along the midline fissure with the sharp edge of forceps. The meninges were gently peeled from the individual cortical lobes and the cortices were dissociated by mechanical digestion [using the cell strainer (BD Bioscience, Franklin Lakes, NJ, USA)] with Dulbecco's modified Eagle's medium (DMEM) containing F12 nutrient mixture (Invitrogen, Carlsbad, CA). The resulting cells were centrifuged (1,500 rpm, $5 \mathrm{~min})$, resuspended in serum-supplemented culture media, and plated into $100 \mathrm{~mm}$ dishes. Serumsupplemented culture media was composed of DMEM supplemented with F12, FBS (5\%), $\mathrm{NaHCO}_{3}(40 \mathrm{mM})$, penicillin (100 units $/ \mathrm{ml})$, and streptomycin $(100 \mu \mathrm{g} / \mathrm{ml})$. The cells were incubated in the culture medium in a humidified incubator at $37^{\circ} \mathrm{C}$ and $5 \% \mathrm{CO}_{2}$ for 9 days. At confluence ( 9 days), the flask was subjected to shaking for $16-18 \mathrm{~h}$ at $37^{\circ} \mathrm{C}$. The cultures were treated for $48 \mathrm{~h}$ with cytosine arabinoside and the medium was replaced with DMEM/F12HAM containing 10\% FBS. The monolayer was treated with $1.25 \%$ trypsin-EDTA for a short duration after which the cells were dissociated and plated into uncoated glass coverslips. The astrocyte cultures formed a layer of process-bearing, glial fibrillary acidic protein (GFAP)-positive cells. The purity of astrocyte cultures was assessed by GFAP-immunostaining. Under these conditions, we can assume that over $95 \%$ of the cells were astrocytes. Microglial BV-2 cells were maintained with serum-supplemented culture media of DMEM supplemented with FBS (5\%), $\mathrm{NaHCO}_{3}(40$ $\mathrm{mM})$, penicillin (100 units $/ \mathrm{ml})$, and streptomycin (100 $\mu \mathrm{g} / \mathrm{ml}$ ). The BV-2 cells were incubated in the culture medium in a humidified incubator at $37^{\circ} \mathrm{C}$ and $5 \% \mathrm{CO}_{2}$. The cultured cells were treated simultaneously with LPS $(1 \mu \mathrm{g} / \mathrm{ml})$ and several concentrations $(0.5,1,2 \mu \mathrm{M})$ of 4$O$-methylhonokiol dissolved in $0.05 \%$ ethanol, and the cells were harvested after $24 \mathrm{~h}$. Western blotting was performed, and $A \beta$ level and secretases activities were determined.

\section{Nitric oxide and $\mathrm{PGE}_{2}$ determination}

Astrocytes were grown in 96-well plates and then incubated with or without LPS $(1 \mu \mathrm{g} / \mathrm{ml})$ in the absence or presence of various concentrations of 4-O-methylhonokiol for $24 \mathrm{~h}$. The nitrite accumulation in the supernatant was assessed by Griess reaction [55]. Each $50 \mu \mathrm{l}$ of culture supernatant was mixed with an equal volume of Griess reagent [0.1\% N-(1-naphthyl)-ethylenediamine, $1 \%$ sulfanilamide in $5 \%$ phosphoric acid] and incubated at room temperature for $10 \mathrm{~min}$. The absorbance at 540 $\mathrm{nm}$ was measured in a microplate absorbance reader, and a series of known concentrations of sodium nitrite was used as a standard. In the cultured supernatant of astrocytes, $\mathrm{PGE}_{2}$ concentration was determined using a $\mathrm{PGE}_{2}$ Enzyme Immunometric Assay (EIA) kit (R\&D systems), according to the manufacturer's instructions. 


\section{Reactive oxygen species (ROS) generation}

To monitor intracellular accumulation of ROS in cultured astrocytes, the fluorescent probe 2',7'-dichlorofluorescein diacetate (DCF-DA) was used. Following treatment with LPS $(1 \mu \mathrm{g} / \mathrm{ml})$ for $24 \mathrm{~h}$ in the presence or absence of $4-O$-methylhonokiol $(0.5,1,2 \mu \mathrm{M})$, the cells were washed in modified Kreb's buffer containing $145 \mathrm{mM} \mathrm{NaCl}, 5 \mathrm{mM}$ potassium chloride $(\mathrm{KCl}), 1 \mathrm{mM}$ magnesium chloride $\left(\mathrm{MgCl}_{2}\right), 1 \mathrm{mM}$ calcium chloride $\left(\mathrm{CaCl}_{2}\right), 4 \mathrm{mM}$ sodium hydrogen carbonate $\left(\mathrm{NaHCO}_{3}\right)$, $5.5 \mathrm{mM}$ glucose, $10 \mathrm{mM}$ HEPES, pH 7.4. The cell suspension was transferred into plastic tubes. Measurement was started by an injection of $5 \mu \mathrm{M}$ DCF-DA in the dark. After $30 \mathrm{~min}$ of incubation at $37^{\circ} \mathrm{C}$, generation was determined by Fluorometer (fmax, Molecular devices corp., Sandiego, CA, USA) at Ex $=485$ and $\mathrm{Em}=538 \mathrm{~nm}$.

\section{Measurement of $A \beta_{1-42}$ and $A \beta_{1-40}$ level}

Lysates of brain tissue, astrocytes and microglial BV-2 cells were obtained through protein extraction buffer containing protease inhibitor. $A \beta_{1-42}$ levels were determined using a specific ELISA Kit (Immuno-Biological Laboratories Co., Ltd., Takasaki-Shi, Gunma, Japan). In brief, $100 \mu \mathrm{l}$ of sample was added into the pre-coated plate and was incubated overnight at $4^{\circ} \mathrm{C}$. After washing each well of the precoated plate with washing buffer, $100 \mu \mathrm{l}$ of labeled antibody solution was added and the mixture was incubated for $1 \mathrm{~h}$ at $4^{\circ} \mathrm{C}$ in the dark. After washing, chromogen was added and the mixture was incubated for $30 \mathrm{~min}$ at room temperature in the dark. Finally, the resulting color was assayed at $450 \mathrm{~nm}$ using a microplate absorbance reader (SunriseTM, TECAN, Switzerland) after adding stop solution.

\section{$\beta$ - and $\gamma$-secretase assay}

The total activities of $\beta$ - and $\gamma$-secretase in the brains and astrocytes were measured using a commercially available $\beta$-secretase (BACE1) fluorescence resonance energy transfer assay kit (PANVERA, Madison, USA) and $\gamma$-secretase activity kit (R\&D Systems, Wiesbaden, Germany) according to the manufacturers' protocols and as described elsewhere [28]. The brains and astrocytes were homogenized in cold $1 \times$ cell extraction buffer (ready for use in the kit) to yield a final protein concentration of $1 \mathrm{mg} / \mathrm{ml}$.

To determine $\beta$-secretase activity, $10 \mu \mathrm{l}$ of lysate was mixed with $10 \mu \mathrm{l}$ of BACE1 substrate (Rh-EVNLDAEFK-Quencher), and then the reaction mixture was incubated for $1 \mathrm{~h}$ at room temperature in the 96 well flat bottom microtitre plate. The reaction was stopped by the addition of $10 \mu \mathrm{l}$ of BACE1 stop buffer $(2.5 \mathrm{M}$ sodium acetate). The formation of fluorescence was read with Fluostar galaxy fluorometer (excitation at $545 \mathrm{~nm}$ and emission at $590 \mathrm{~nm}$ ) with Felix software (BMG Labtechnologies, Offenburg, Germany). The enzyme activity was linearly related to the increase in fluorescence. The enzyme activity was expressed as nM produced substrate which was determined by the formation of fluorescence per mg protein per min. All controls, blanks and samples were run in triplicate.

To determine $\gamma$-secretase activity, $50 \mu \mathrm{l}$ of lysate was mixed with $50 \mu \mathrm{l}$ of reaction buffer. The reaction mixture was then incubated for $1 \mathrm{~h}$ in the dark at $37^{\circ} \mathrm{C}$ followed by the addition of $5 \mu$ l of substrate. Cleaved substrate by $\gamma$-secretase was conjugated to the reporter molecules EDANS and DABCYL, and released fluorescent signal. This formation of fluorescence was read with Fluostar galaxy fluorometer (excitation at $355 \mathrm{~nm}$ and emission at $510 \mathrm{~nm}$ ) with Felix software (BMG Labtechnologies, Offenburg, Germany). The level of $\gamma$-secretase enzymatic activity is proportional to the fluorometric reaction, and the $\gamma$-secretase activity was expressed as the produced fluoresce unit.

\section{Nuclear extraction and gel mobility shift assay}

Gel mobility shift assay was conducted using a slight modification of a previously described method [44]. In brief, $10 \mu \mathrm{g}$ of nuclear protein of astrocytes was incubated in $25 \mu \mathrm{L}$ of total volume of incubation buffer (10 mmol/L Tris, $\mathrm{pH} 7.5,100 \mathrm{mmol} / \mathrm{L} \mathrm{NaCl}, 1 \mathrm{mmol} / \mathrm{L}$ dithiothreitol, $4 \%$ glycerol, $80 \mathrm{mg} / \mathrm{L}$ salmon sperm DNA) at $4^{\circ} \mathrm{C}$ for $15 \mathrm{~min}$ followed by another $20 \mathrm{~min}$ incubation with $9.25 \mathrm{mBq}\left[\gamma_{-}{ }^{32} \mathrm{P}\right]$ ATP-labeled oligonucleotide containing the NF- $\kappa \mathrm{B}$ binding site at room temperature. The DNA-protein binding complex was electrophoretically resolved on a $6 \%$ nondenatured polyacrylamide gel at 150 volts for $2 \mathrm{~h}$. The gels were dried and autoradiographed using Kodak MR film at $-80^{\circ} \mathrm{C}$ overnight.

\section{Quantitative real-time PCR}

For mRNA quantification, total RNA was extracted using the RNAqueous kit (Applied Biosystems, Foster city, CA). The cDNA was synthesized using High Capacity RNAto-cDNA kit (Applied Biosystems, Foster city, CA) according to the manufacturer's protocol. Briefly, $1 \mu \mathrm{g}$ of total RNA was used for cDNA preparation. Quantitative real-time PCR was performed on cDNA using TaqMan Gene Expression Assays (Applied Biosystems, Foster City, CA) specific for glyceraldehyde-3-phosphate dehydrogenase (GAPDH; assay no. Mm99999915_g1), TNF- $\alpha$ (Mm00443258_m1) and IL-1 $\beta$ (Mm00434228_m1). All reverse transcription reactions were run in a 7500 RealTime PCR System (Applied Biosystems, Foster city, CA) using the universal cycling parameters $\left(20 \mathrm{~s} 95^{\circ} \mathrm{C}, 60\right.$ cycles of $3 \mathrm{~s} 95^{\circ} \mathrm{C}, 30 \mathrm{~s} 60^{\circ} \mathrm{C}$ ). The values obtained for the target gene expression were normalized to GAPDH 
and quantified relative to the expression in control samples. For the calculation of relative quantification, the $2^{-}$ ${ }^{\triangle} \mathrm{CT}$ formula was used, where:

$-\Delta \Delta \mathrm{CT}=\left(C_{\mathrm{T}, \text { target }}-C_{\mathrm{T}, \mathrm{GAPDH}}\right)$ experimental sample $-\left(C_{\mathrm{T}, \text { target }}-C_{\mathrm{T}, \mathrm{GAPDH}}\right)$ control sample.

\section{Western blotting}

An equal amount of total protein $(40 \mu \mathrm{g})$ was resolved on an SDS/10 or $15 \%$ polyacrylamide gel and then transferred to a polyvinylidene difluoride membrane (GE Water and Process Technologies, Trevose, PA, USA). The membrane was incubated at room temperature with specific antibodies. To detect target proteins, specific antibodies against BACE1 (1:500, Sigma, St. Louis, MO, USA), C99, APP (1:500, ABR-affinity Bioreagents, Golden, CO, USA), A $\beta$ (1:500, 4G8, Covance, Berlely, CA, USA), cleaved caspase-3 (1:200, Cell Signaling Technology, Inc., Beverly, MA, USA), COX-2 (1:1000, Cayman Chemical, Ann Arbor, MI, USA), iNOS (1:1000, Abcam), p65, I $\kappa$ B, pI $\kappa \mathrm{B}(1: 500$, Santa Cruz Biotechnology Inc. Santa Cruz, CA, USA) and p50 (1:500, Santa Cruz Biotechnology Inc. Santa Cruz, CA, USA) were used. The blot was then incubated with the corresponding conjugated anti-mouse IgG-horseradish peroxidase (1:4000, Santa Cruz Biotechnology Inc. Santa Cruz, CA, USA). Immunoreactive proteins were detected with an enhanced chemiluminescence western blotting detection system. The relative density of the protein bands was scanned by densitometry using MyImage (SLB, Seoul, Korea), and quantified by Labworks 4.0 software (UVP Inc., Upland, CA, USA).

\section{Immunohistochemistry and immunofluorescence}

Brains were fixed in formalin and paraffin-enclosed for examination. Five-micrometer-thick tissue sections were used with immunohistochemistry. Paraffin-embedded sections were deparaffinized and rehydrated, washed in distilled water, and then subjected to heat-mediated antigen retrieval treatment. Endogenous peroxidase activity was quenched by incubation in $2 \%$ hydrogen peroxide in methanol for $15 \mathrm{~min}$ and then cleared in PBS for $5 \mathrm{~min}$. The sections were blocked for $30 \mathrm{~min}$ with 3\% normal horse serum diluted in PBS. These sections were incubated for overnight with appropriate antibodies; $A \beta_{1-42}$ (1:2000, Clone No. 4 G8, Covance, Berkeley, CA, USA), GFAP (1:5000, Abcam, Inc, Cambridge, MA, USA), COX-2 (1:100, Cayman Chemical, Ann Arbor, MI, USA), iNOS (1:100, Abcam) and cleaved caspase-3 (1:200, Cell Signaling Technology, Inc.). After the incubation, sections were washed in PBS and incubated with the biotinylated secondary antibodies (ABC kit, Vector Laboratories, Burlingame, CA) for $1 \mathrm{~h}$. The sections were washed with PBS, incubated with the avidin-biotin complex (Vector Laboratories) for 30 min, and visualized by chromogen DAB (Vector Laboratories) reaction. It was then counterstained by a hematoxylin. Finally, sections were dehydrated in ethanol, cleared in xylene, and mounted with Permount (Fisher Scientific, Hampton, NH), and evaluated on a light microscopy (Olympus, Tokyo, Japan). To determine the expression of iNOS, BACE, GFAP and cleaved caspase3 , the stained cells by each antibody were counted. The six sections with three different animal brains were analyzed, and cells at three randomly selected areas $(100 \times$ $100 \mu \mathrm{m})$ in each section were assessed. The immunoreactive cells by anti-iNOS, BACE, GFAP and cleaved caspase- 3 antibody were counted, and expressed as percentage of stained cells. The quantity of reactive cells was expressed as the average number of reactive cells per high power field (visible reactive cells/HPF). To simultaneously determine level of GFAP and $A \beta$, we performed immunofluorescence assay in paraffin section of brain. The sections were then incubated to primary rabbit polyclonal antibody for GFAP (1:1000, Abcam, Inc, Cambridge, MA, USA) and mouse monoclonal antibody for $A \beta_{1-42}$ (1:2000, Clone No. 4 G8, Covance, Berkeley, CA, USA) overnight at $4^{\circ} \mathrm{C}$. After washes with ice-cold PBS, followed by treatment with an anti-rabbit secondary antibody labeled with Alexa Fluor 568 and anti-mouse secondary antibody labeled with Alexa Flour 488 (1:100 dilution, Molecular Probes, Inc., Eugene, OR) for $2 \mathrm{hr}$ at room temperature, immunofluorescence images were acquired using a confocal laser scanning microscope (TCS SP2, Leica Microsystems AG, Wetzlar, Germany). Areas of amyloid deposition in mice brain were identified by staining of $0.2 \%$ congo-red (Sigma) solution or $0.2 \%$ thioflavine S (Sigma) as described in detail in Wilcock et al. [56] and microscopic evaluation. For quantification of congophilic plaque load, digital images were captured at $10 \times$ magnification on an Olympus IX70 Imaging System using a single exposure setting as follows: the entire hippocampus (2 images); the visual (1 image), somatosensory (1 image) and somatomotor (1 image) cortex. Images were converted to gray scale and the threshold intensity was set to the intensity observed in areas without tissue. Plaque load was defined as the $\%$ area, i.e. the positive area/total area $\times 100$. The data were expressed as the mean \pm SEM ( $\mathrm{n}=6$ for each group).

\section{Measurement of apoptotic cells}

The terminal deoxynucleotidyltransferase (TdT)mediated dUTP-biotin nick end-labeling (TUNEL) assays were performed by using the in situ cell death detection kit (Roche Diagnostics GmbH, Mannheim, Germany) according to the manufacturer's protocol. 
TUNEL mixture was added onto tissue sections and incubated in a humidified chamber for $60 \mathrm{~min}$ at $37^{\circ} \mathrm{C}$. After each step, the tissue sections were rinsed twice with a phosphate-buffered saline (PBS, pH 7.4). For DAPI staining, brains were incubated for $30 \mathrm{~min}$ at room temperature in the dark. The cells were then observed through a fluorescence microscope (Leica Microsystems AG, Wetzlar, Germany). Total number of cells in given area was determined by using DAPI nuclear staining. The apoptotic bodies (TUNEL-stained cells) were identified under a fluorescencemicroscope (x200) containing green colored nuclei. The quantity of apoptotic bodies was expressed as the average number of apoptotic cells per high power field (visible apoptotic cells/HPF).

\section{Measurement of TNF- $\alpha$ and IL-1 $\beta$}

TNF $-\alpha$ and IL- $1 \beta$ concentrations were measured in supernatant of astrocytes using ELISAs specific for rat TNF- $\alpha$, and IL-1 $\beta$ (Assay Designs, Ann Arbor, Michigan), respectively, according to the manufacturer's instructions. After samples and standards were added to wells, plates were incubated for $1 \mathrm{~h}$ at $37^{\circ} \mathrm{C}$. Wells were washed 7 times with wash solution, at which point antibody was added to each well and incubated for $30 \mathrm{~min}$ at $4^{\circ} \mathrm{C}$. After two additional wash procedures, substrate solution was added to each well, and plates were further incubated for $30 \mathrm{~min}$ at room temperature in the dark, at which point stop solution was added to all wells. Finally, the resulting color was assayed at $450 \mathrm{~nm}$ using a microplate absorbance reader (SunriseTM, TECAN, Switzerland).

\section{Statistical analysis}

Statistical analysis of the data was carried out using analysis of variance (ANOVA) for repeated measures followed by Dunnette's post-hoc analysis using GraphPad Prism 4 software (Version 4.03, GraphPad software, Inc., La Jolla, USA).

\section{Results}

\section{Effect of 4-O-methylhonokiol on LPS-induced memory impairment}

To investigate the memory-improving effects by 4$O$-methylhonokiol on the LPS-induced memory impairment model, mice were continuously administered 4-Omethylhonokiol at a dose of 0.5 or $1 \mathrm{mg} / \mathrm{kg} /$ day daily for 3 weeks (from day 1 to day 28), and then by i.p. injection with $250 \mu \mathrm{g} / \mathrm{kg} /$ day LPS daily for 1 week (from day 22 to day 28) as shown in Figure 1B. The mice were trained in the Morris water maze test of 15 times training (3 times per day for 5 days). After training, LPStreated mice slowly arrived at the location of the platform, thus demonstrating memory impairments compared to the control group, but 4-O-methylhonokiol significantly ameliorated these memory-impaired effects of LPS-injected mice on escape latencies (in both $\mathrm{cm}$ and s) (Figure 2A and 2B). Swimming speed did not differ among the groups (data not shown). The mice exhibited shorter and shorter escape latencies at the end of the training trial, and the average swimming distance and escape latency at the end of training to the platform were about $664.7 \pm 133.2 \mathrm{~cm}$ and $26.4 \pm 2.6 \mathrm{~s}$ after 15 times training trial in the control (saline) group. LPSinjected mice exhibited average swimming distance and escape latency to the platform about $1125.2 \pm 211.4 \mathrm{~cm}$ and $40.2 \pm 4.0 \mathrm{~s}$ (Figure $2 \mathrm{~A}$ and $2 \mathrm{~B}$ ). However, the mice that were given 0.5 and $1 \mathrm{mg} / \mathrm{kg}$ of 4-O-methylhonokiol at day 5 showed a significant and dose-dependent decrease to $669.9 \pm 200.6 \mathrm{~cm}$ and $26.6 \pm 6.9 \mathrm{~s}$, and $473.5 \pm 114.2 \mathrm{~cm}$ and $20.4 \pm 3.7 \mathrm{~s}$, respectively.

One day after the water maze test, we performed a probe trial to measure the maintenance of memory function. During this trial, the average time spent on the target quadrant was decreased in the LPS-injected mice $(21.57 \pm 2.57 \%)$ compared to the control mice $(32.13 \pm$ $3.60 \%)$, but administration of 4-O-methylhonokiol $(0.5$ or $1 \mathrm{mg} / \mathrm{kg} /$ day) in the memory impaired mice significantly increased average time spent to $32.36 \pm 4.27 \%$ and $34.62 \pm 2.40 \%$ (Figure $2 \mathrm{C}$ ). one day after the probe trial, a step-through test was performed. Treatment with LPS $(250 \mu \mathrm{g} / \mathrm{kg}$ i.p.) significantly decreased the stepthrough latency (as determined by passive-avoidance performance in comparison to the control group); however, 4-O-methylhonokiol significantly prevented this decreased step-through latency (Figure 1D). The control group exhibited an average step-through latency of 93.6 $\pm 33.3 \mathrm{~s}$ in the illuminated compartment, whereas that of the LPS-treated group decreased to $24.8 \pm 11.5 \mathrm{~s}$. 4-O-methylhonokiol-treated mice were recovered to $62.1 \pm 31.9 \mathrm{~s}$ and $138.4 \pm 29.7 \mathrm{~s}$ from the LPS-induced step-through latency in a dose-dependent manner (Figure 2D).

\section{4-O-methylhonokiol inhibits LPS-induced iNOS and COX-2 expression}

To investigate the inhibitory effect of 4-O-methylhonokiol on memory impairment via inhibition of neuroinflammation, the expression of iNOS was determined by immunohistochemical analysis. Upon LPS treatment, the number of brown-colored (iNOS-labeled) cells in both the cortex and hippocampus of LPS-injected mice was significantly higher than those in control mice, but 4-Omethylhonokiol treatment lowered this number (Figure $3 \mathrm{~A}$ and $3 \mathrm{~B})$. Paralleled with the expression level of iNOS detected by immunohistochemical analysis, western blot analysis showed that iNOS expression was significantly increased by LPS injection in mice brain while 


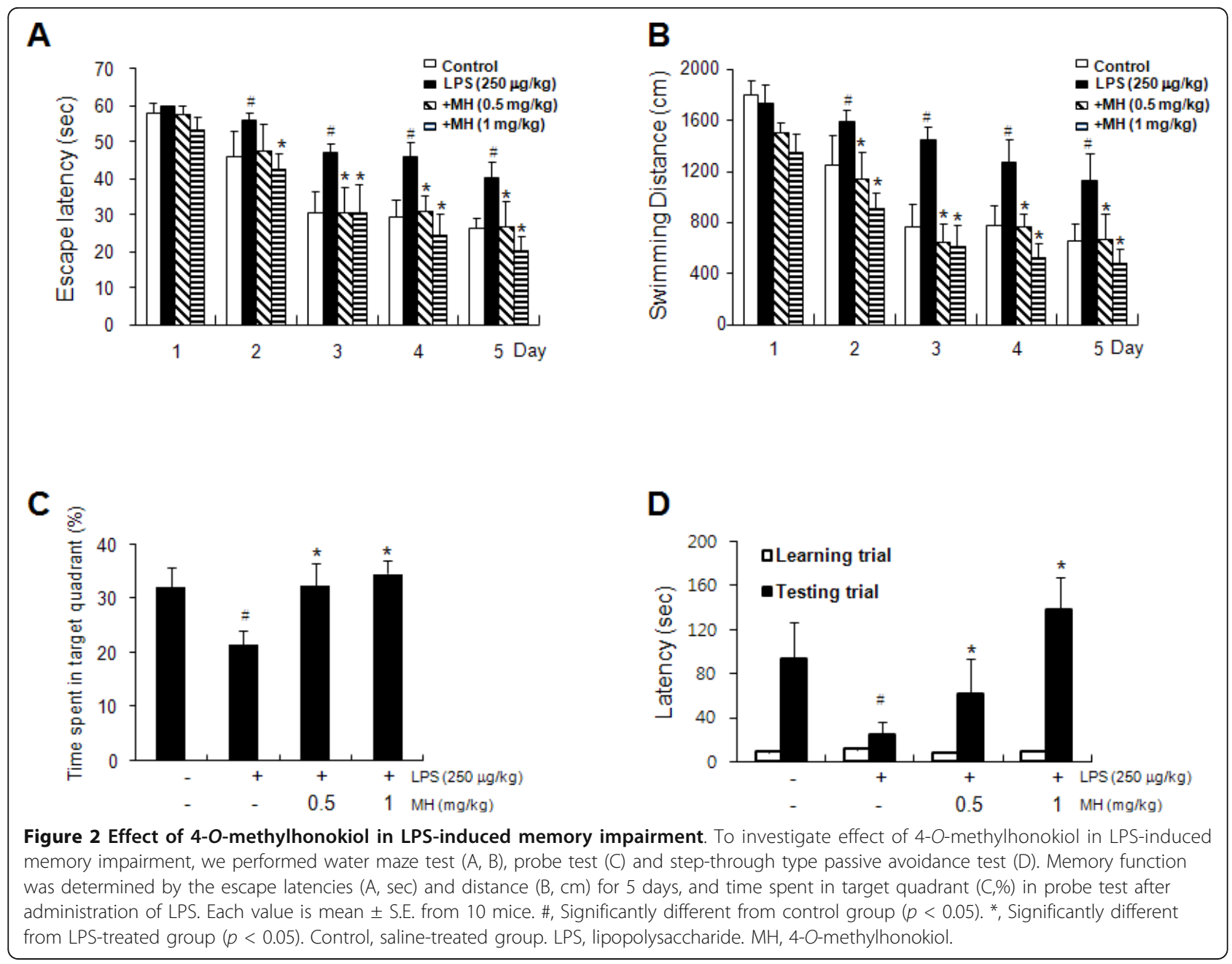

densitometry data showed that LPS-induced iNOS expression was significantly inhibited by $4-O$-methylhonokiol (Figure 3C). Since NO can induce COX-2 expression, and COX-2 is also an enzyme that regulates inflammation, we investigated the expression of $\mathrm{COX}-2$ and found that 4-O-methylhonokiol also inhibited the LPS-induced COX-2 expression (Figure 3C).

\section{Effect of 4-O-methylhonokiol against the $A \beta_{1-42}$} accumulation in LPS-injected mice brain

We determined the effect of 4-O-methylhonokiol on the levels of $A \beta_{1-42}$ in the cerebral cortex and hippocampus of LPS-injected mice, since the accumulation of $A \beta_{1-42}$ has been implicated in memory dysfunction. We found that, similar to previous data [42], the number of brown colored ( $\mathrm{A} \beta_{1-42}$-labeled) cells in both the cortex and hippocampus of LPS-injected mice was significantly higher than that in control mice, but 4-O-methylhonokiol treatment lowered the increased number of $A \beta_{1-42}$-labeled cells (Figure 4A). In addition, these results could confirm the LPS-induced increase of amyloid plaque using congo red and thioflavin $\mathrm{S}$, and confirm that 4-Omethylhonokiol decreases amyloid plaque (Figure 4B and $4 \mathrm{C}$ ). Paralleled with the reduced $A \beta_{1-42}$ reactive cell number, the level of $A \beta_{1-42}$ (Figure 4D) and the activity of $\beta$ - and $\gamma$-secretases (Figure 4E) were also significantly reduced in 4-O-methylhonokiol-treated whole brains of LPS-injected mice. Moreover, the expression of the neuronal BACE1 as well as reactive cell number of BACE1 was significantly reduced by the treatment of 4-Omethylhonokiol (Figure 5A and 5B). To confirm these results, we investigated the levels of APP, C99, and BACE1 proteins using western blot analysis. Both the expression level of APP and C99 increased in the brains of LPS-injected mice, and these elevations were reduced by the treatment of 4-O-methylhonokiol (Figure 5C).

\section{Effect of 4-O-methylhonokiol on the activation of} astrocytes and microglia in LPS-injected mice brain Activation of neuroglia has also been implicated in amyloidogenesis and neuronal cell death during the development of AD [57]. To investigate the protective effect of 


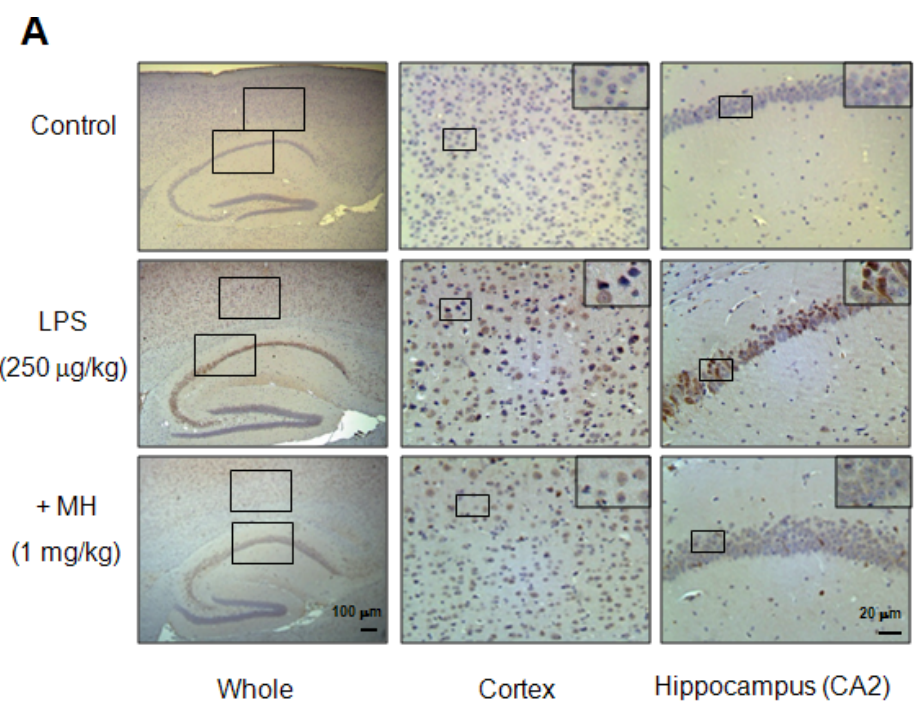

B

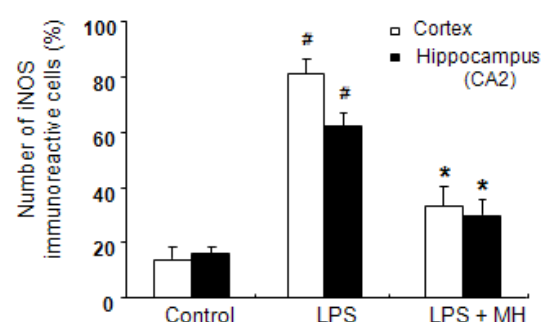

C

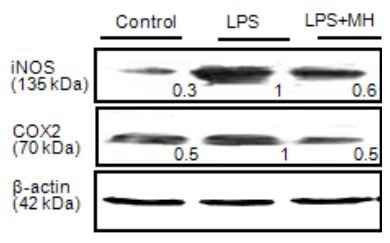

Figure 3 Inhibitory effects of 4-O-methylhonokiol on the LPS-induced expression of inflammatory proteins. (A) Immunoreactive cells of iNOS antibody were detected in the cortex and hippocampus. $5 \mu$ m-thick sections of brains from mice were incubated with anti-iNOS antibodies and the biotinylated secondary antibody. It was then counterstained by hematoxylin. The resulting tissue was viewed with a microscope. (B) The present figure is representative for three different experiments with different animal brains. (C) The expression of iNOS and COX-2 were detected by western blotting using specific antibodies. $\beta$-Actin protein was used here as an internal control. The values in the western blot band indicate average density over $\beta$-actin from 5 animals. \#, Significantly different from control group $(p<0.05)$. ${ }^{*}$, Significantly different from LPS-treated group $(p<0.05)$. Control, saline-treated group. LPS, lipopolysaccharide. MH, 4-O-methylhonokiol.

4-O-methlyhonokiol on activation of astrocytes and microglia, we performed an immunohistochemical analysis of GFAP- and Iba1-reactive cells in the brain. In the LPS-injected mice, GFAP- and Iba1-reactive cell numbers were significantly higher whereas the treatment of 4-O-methlylhonokiol reduced the number of GFAP reactive cells in the cortex and hippocampus (Figure 6A and $6 \mathrm{~B})$. Paralleled with the immunohistochemical results, western blot analysis also showed that GFAP and Iba1 levels were increased in the brains of LPSinjected mice, and these levels were then reduced by the treatment of 4-O-methylhonokiol (Figure 6C). To demonstrate more clearly that the activation of astrocytes could cause $A \beta$ generation, co-immunoreactive cells against GFAP and $A \beta_{1-42}$ were identified by means of double immunofluorescence method (Figure 6D). The co-reactive cell number for both markers was significantly increased by LPS, but was lowered by 4-Omethylhonokiol treatment.
Next, to investigate both the consequence of neuroglia activation and amyloidogenesis by LPS and the protective effect of 4-O-methylhonokiol, cell death was investigated by determining the expression levels of the proapoptotic protein, cleavage caspase-3. LPS-injection induced higher expressions of cleavage caspase-3, but treatment with 4-O-methylhonokiol decreased this expression as determined by immunohistochemical (Figure 7A) and western blot analysis (Figure 7C). In addition, to confirm LPS-induced neuronal cell death, we performed TUNEL assay. Paralleled with results of cleavage caspase-3, LPS-injection increased number of apoptotic neuronal cells, and treatment with 4-Omethylhonokiol decreased number of apoptotic cells.

Effect of 4-O-methylhonokiol on LPS-induced release of NO, PGE 2 , ROS, TNF- $\alpha$ and IL-1 $\beta$ in cultured astrocytes

To further investigate the anti-neuroinflammatory and anti-amyloidogenesis effects of 4-O-methylhonokiol in 


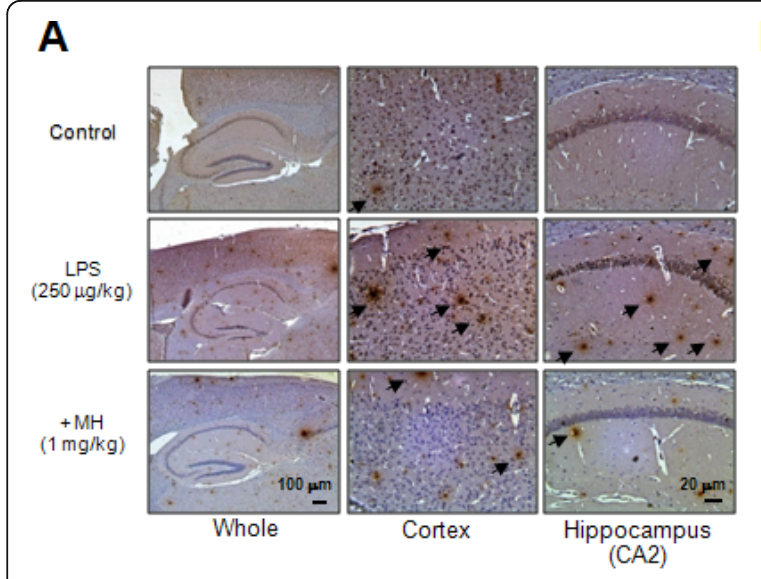

B

C

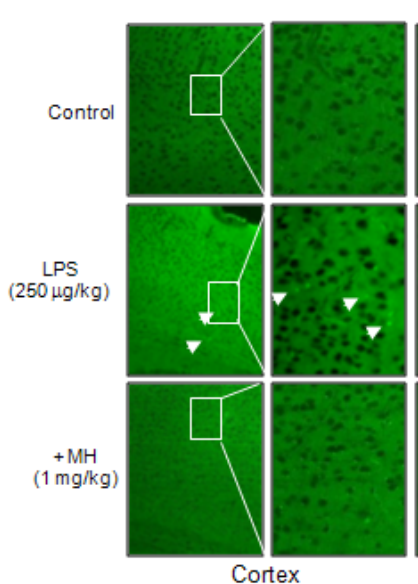

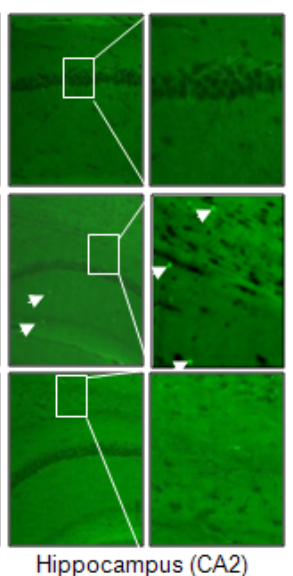

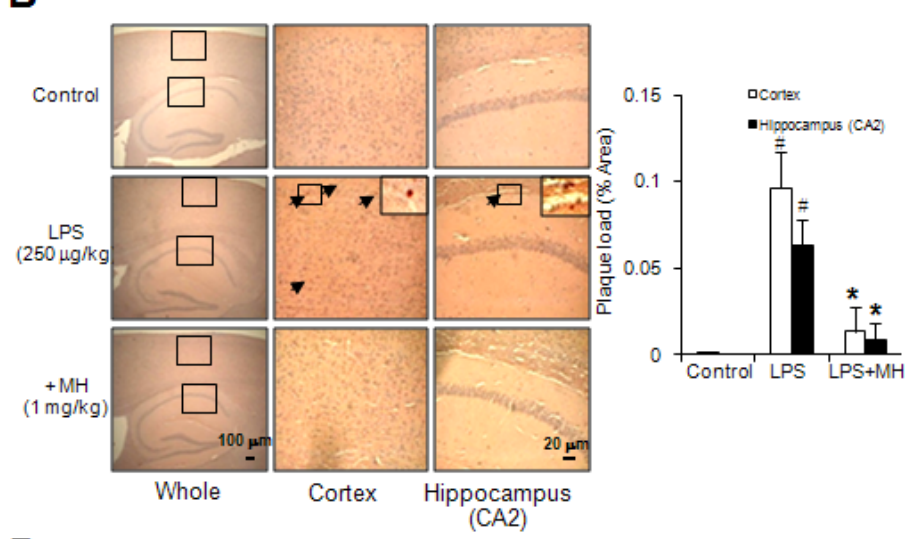

D
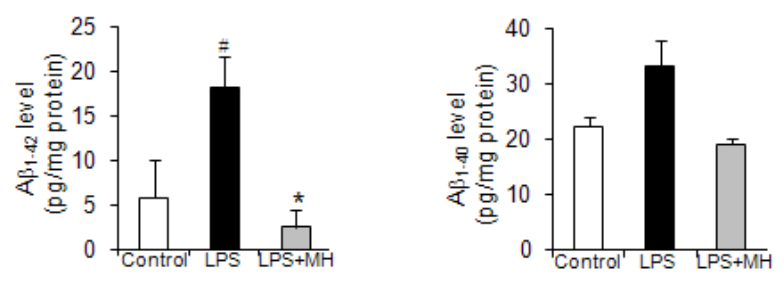

E
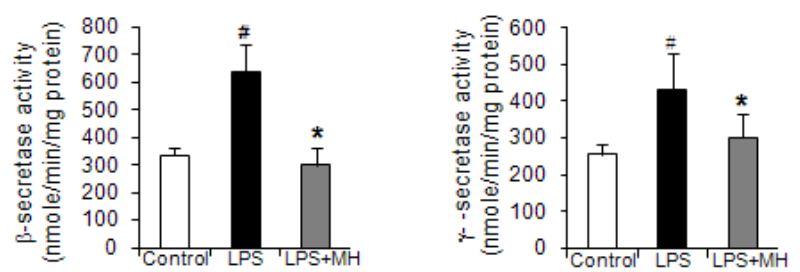

Figure 4 Effect of $\mathbf{4}-\boldsymbol{O}$-methylhonokiol on $\mathbf{A} \boldsymbol{\beta}$ accumulation in the cortex and hippocampus. (A) Immunoreactive protein of anti-A $\boldsymbol{\beta}_{1-42}$ antibody was investigated in the cortex and hippocampus. $6 \mu \mathrm{m}$-thick sections of brains from mice were incubated with anti-A $\beta_{1-42}$ antibody and counterstained with hematoxylin. Arrow indicates $A \beta_{1-42}$ accumulation which is clearly higher in the cerebral cortex and hippocampus of LPS-injected mouse. Amyloid plaque detection via congo red staining (B) and thioflavin $S$ (C) was performed in the cortex and hippocampus. 6 $\mu \mathrm{m}$-thick sections of brains were incubated with $0.2 \%$ congo red solution or thioflavin S solution for 20 min and counterstained with hematoxylin. Arrow indicates amyloid plaque which is clearly higher in the cerebral cortex and hippocampus of LPS-injected mouse. The histograms depict the mean congophilic plaque load \pm SEM in mice brain. (D) The levels of $A \beta_{1-42}$ and $A \beta_{1-40}$ were assessed by using a specific A $\beta$ ELISA as described in Methods. (E) The activity of $\beta$ - and $\gamma$-secretase was investigated by using each assay kit as described in Methods. Values measured from each group of mice were calibrated by amount of protein and expressed as mean \pm S.E. ( $n=5$ ). The values in the western blot band indicate average density over $\beta$-actin from three animals. \#, Significantly different from control group ( $p<0.05)$. ${ }^{*}$, Significantly different from LPS-treated group ( $p<0.05$ ). Control, saline-treated group. LPS, lipopolysaccharide. MH, 4-O-methylhonokiol.

cultured astrocytes, which are responsible for neuroinflammation and amyloidogenesis in the brain, we examined the inhibitory effect of 4-O-methylhonokiol on the LPS $(1 \mu \mathrm{g} / \mathrm{ml})$-induced $\mathrm{NO}$ and $\mathrm{PGE}_{2}$ production as well as expression of iNOS and COX-2 in cultured astrocytes. After co-treatment with LPS and 4-O-methylhonokiol $(0.5,1$ and $2 \mu \mathrm{M})$ for $24 \mathrm{~h}$, LPS-induced nitrate concentrations in the medium were decreased remarkably in a concentration-dependent manner (Figure 8A). We further investigated the effects of 4-O-methylhonokiol on the LPS-induced synthesis of $\mathrm{PGE}_{2}$, the major product of COX-2 enzymatic activity. While LPS induced a marked synthesis of $\mathrm{PGE}_{2}, 4-O$-methylhonokiol blocked LPS- induced $\mathrm{PGE}_{2}$ synthesis (Figure $8 \mathrm{~B}$ ). To study the protective effect of 4-O-methylhonokiol against the LPS-induced activation of astrocytes, we investigated the release of ROS, TNF- $\alpha$ and IL- $1 \beta$ was determined as indicators of astrocytes activation as well as inflammatory responses. We found that treatment of 4-O-methylhonokiol reduced LPS-induced ROS generation (Figure 8C). LPS-induced TNF- $\alpha$ and IL- $1 \beta$ release in cultured astrocytes was also reduced by 4-O-methylhonokiol in a concentrationdependent manner (Figure 8D, E, F, G and 8H).

Effect of 4-O-methylhonokiol on LPS-induced NF- $\kappa \mathrm{B}$ transcriptional and DNA-binding activity as well as iNOS and COX-2 expression in cultured astrocytes 


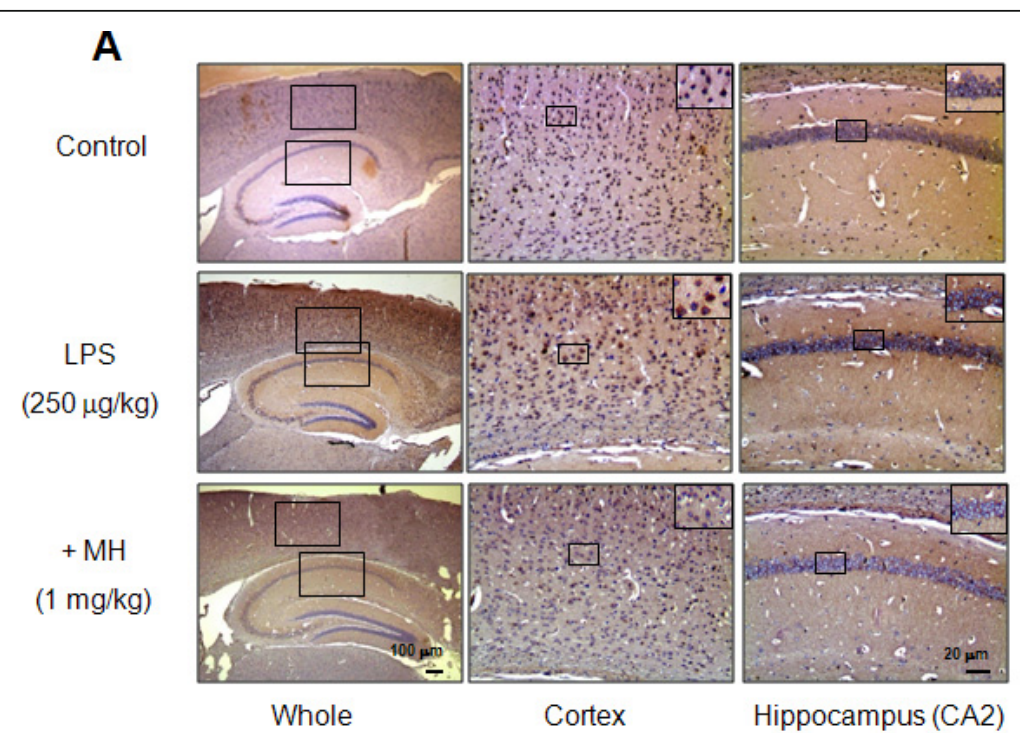

B

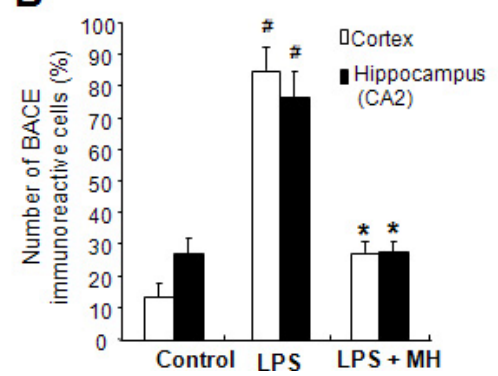

C

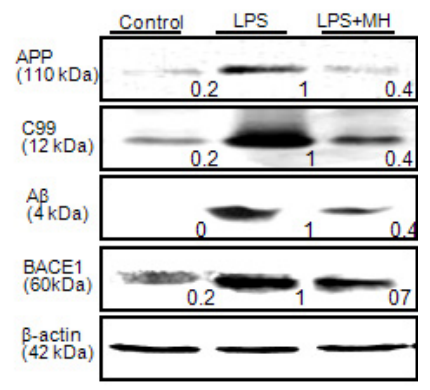

Figure 5 Effect of 4-O-methylhonokiol on expression of amyloidogenic proteins. (A) Immunoreactive cells of anti-BACE1 antibody were investigated in the cortex and hippocampus. (B) The present figure is representative for three different experiments with different animal brains. (C) The expression of APP, C99 and BACE1 were detected by western blotting using specific antibodies in mice brain. $\beta$-Actin protein was used as an internal control. Each blot is representative for three experiments. The values in the western blot band indicate average density over $\beta$ actin from 5 animals. \#, Significantly different from control group $(p<0.05)$. *, Significantly different from LPS-treated group $(p<0.05)$. Control, saline-treated group. LPS, lipopolysaccharide. $\mathrm{MH}$, 4-O-methylhonokiol.

It has been demonstrated that LPS activates transcription factor NF- $\kappa$ B leading to the increased expression of many immediate-early genes, including the amyloidogenesis-related enzymes, such as BACE1. Thus, our next step was to investigate NF- $\kappa$ B DNA-binding activity. LPS-induced NF- $\kappa$ B DNA binding activity in cultured astrocytes was decreased by 4-O-methylhonokiol in a concentration-dependent manner (Figure 9A). This DNA-binding activity of NF- $\kappa$ B was confirmed by super shift assays. In the presence of a p50 antibody, the DNAbinding activities of NF- $\kappa \mathrm{B}$ showed a super shift. However, in the presence of a 065 antibody, the DNA-binding activity of NF- $\kappa \mathrm{B}$ was decreased without a super shift, suggesting that p50 might be a target of 4-O-methylhonokiol, interfering with the DNA-binding activity of NF- $\kappa \mathrm{B}$ (Figure 9B). To clarify the action mechanism of 4-O-methylhonokiol on NF- $\kappa \mathrm{B}$ activity, the nuclear translocation of p50 and p65 was examined. In the presence of 4-O- methylhonokiol, LPS-induced nuclear translocation of p50 and p65 in astrocytes was inhibited in a concentration-dependent manner (Figure 9C). Moreover, 4-Omethylhonokiol inhibited LPS-induced degradation of $\mathrm{I} \kappa \mathrm{B} \alpha$ via inhibition of $\mathrm{I} \kappa \mathrm{B} \alpha$ phosphorylation (Figure 9C). To examine the consequence of the inhibitory effects of 4$O$-methylhonokiol on NF- $\kappa \mathrm{B}$ activity, expression of the NF- $\kappa \mathrm{B}$-derived inflammatory genes, iNOS and COX-2, was investigated. As shown in Figure 9D, the cells expressed extremely low levels of iNOS in the unstimulated condition. However, iNOS expression was markedly increased in response to LPS after $24 \mathrm{~h}$. Treatment with 4$O$-methylhonokiol $(0.5,1$ and $2 \mu \mathrm{M})$ concentration-dependently decreased LPS-induced expression of iNOS in cultured astrocytes. These results indicate that 4-Omethylhonokiol may inhibit the LPS-induced activation of $\mathrm{NF}-\kappa \mathrm{B}$ via inhibition of $\mathrm{I} \kappa \mathrm{B} \alpha$ degradation, as well as via the translocation of p50 and p65 into the nucleus, and this 


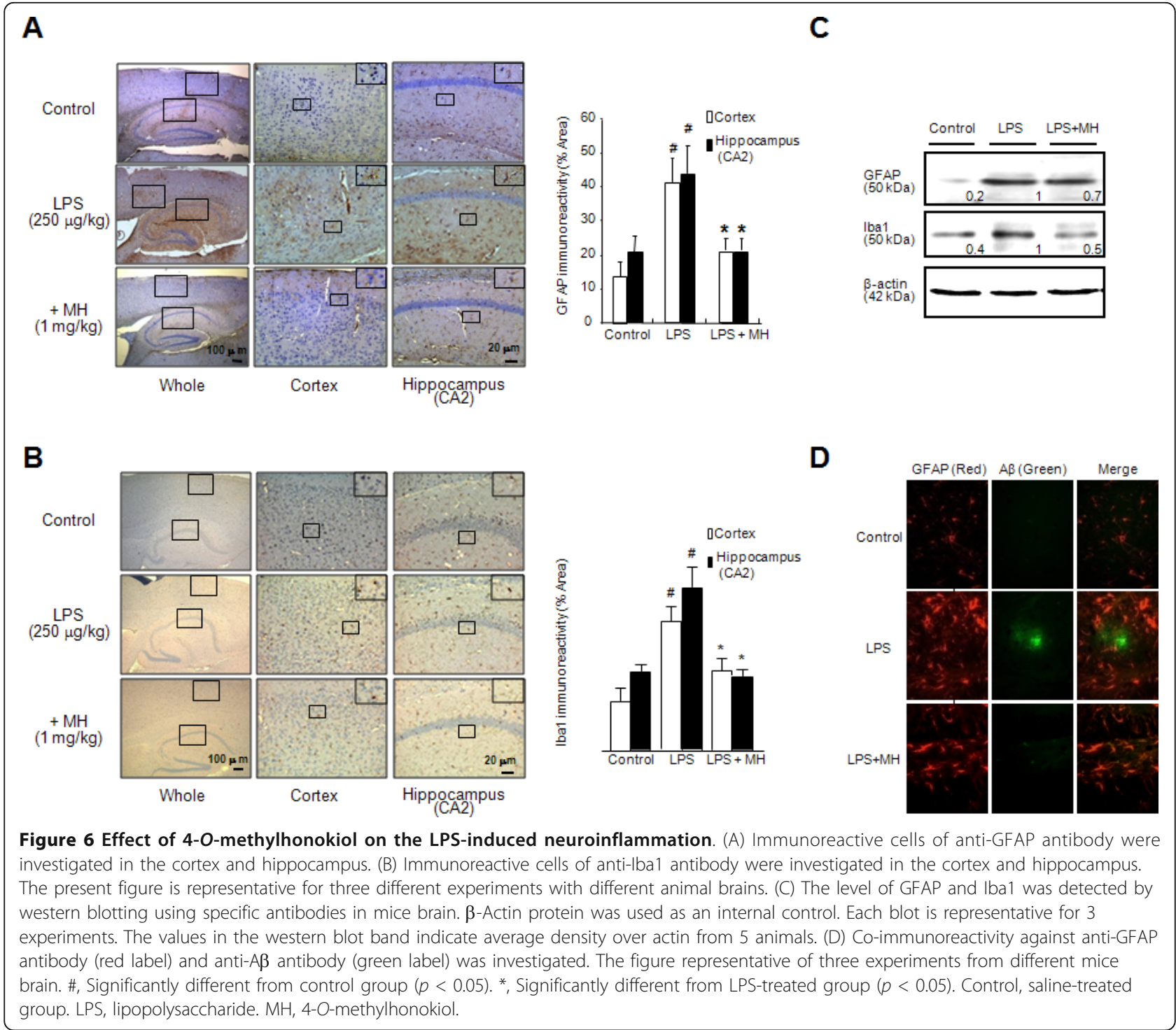

effect may result in the inhibition of LPS-induced expression of iNOS and COX-2.

\section{Effect of 4-O-methylhonokiol on LPS-induced amyloidogenesis in cultured astrocytes and microglial BV-2 cells}

It is known that the activation of microglia and astrocytes are major sources of neuro-inflammation. Increasing evidence indicates that inflammatory stimuli concomitantly increase amyloidogenesis in astrocytes. Thus, we investigated whether 4-O-methylhonokiol prevented LPSinduced amyloidogenesis. Low levels of APP, BACE and C99 protein were found in the unstimulated control condition, whereas the expression of BACE, APP and C99 proteins increased in response to LPS $(1 \mu \mathrm{g} / \mathrm{ml})$ after 24 h. Treatment with 4-O-methylhonokiol $(0.5,1$ and $2 \mu \mathrm{M})$ caused a concentration-dependent inhibition in LPS- induced BACE, C99 and APP expression in astrocytes and in microglial BV-2 cells (Figure 9D and 9H). We also determined the effect of 4-O-methylhonokiol on the levels of $A \beta_{1-42}$ in the LPS-stimulated astrocytes and microglial BV-2 cells, and found a significantly higher level of $A \beta_{1-42}$ in the LPS group compared to levels in control cells. 4-O-methylhonokiol treatment, however, lowered this increased level of $\mathrm{A} \beta_{1-42}$ (Figure 9E and 9I). Paralleled with the reduced level of $A \beta_{1-42}$, activity of $\beta$ and $\gamma$-secretase were also significantly reduced by $4-O-$ methylhonokiol in LPS-stimulated astrocytes (Figure 9F and 9G).

\section{Discussion}

The most important finding of this study is that 4-Omethylhonokiol, a lignan compound isolated from $\mathrm{Mag}$ nolia officinalis, suppressed amyloidogenesis via its anti- 


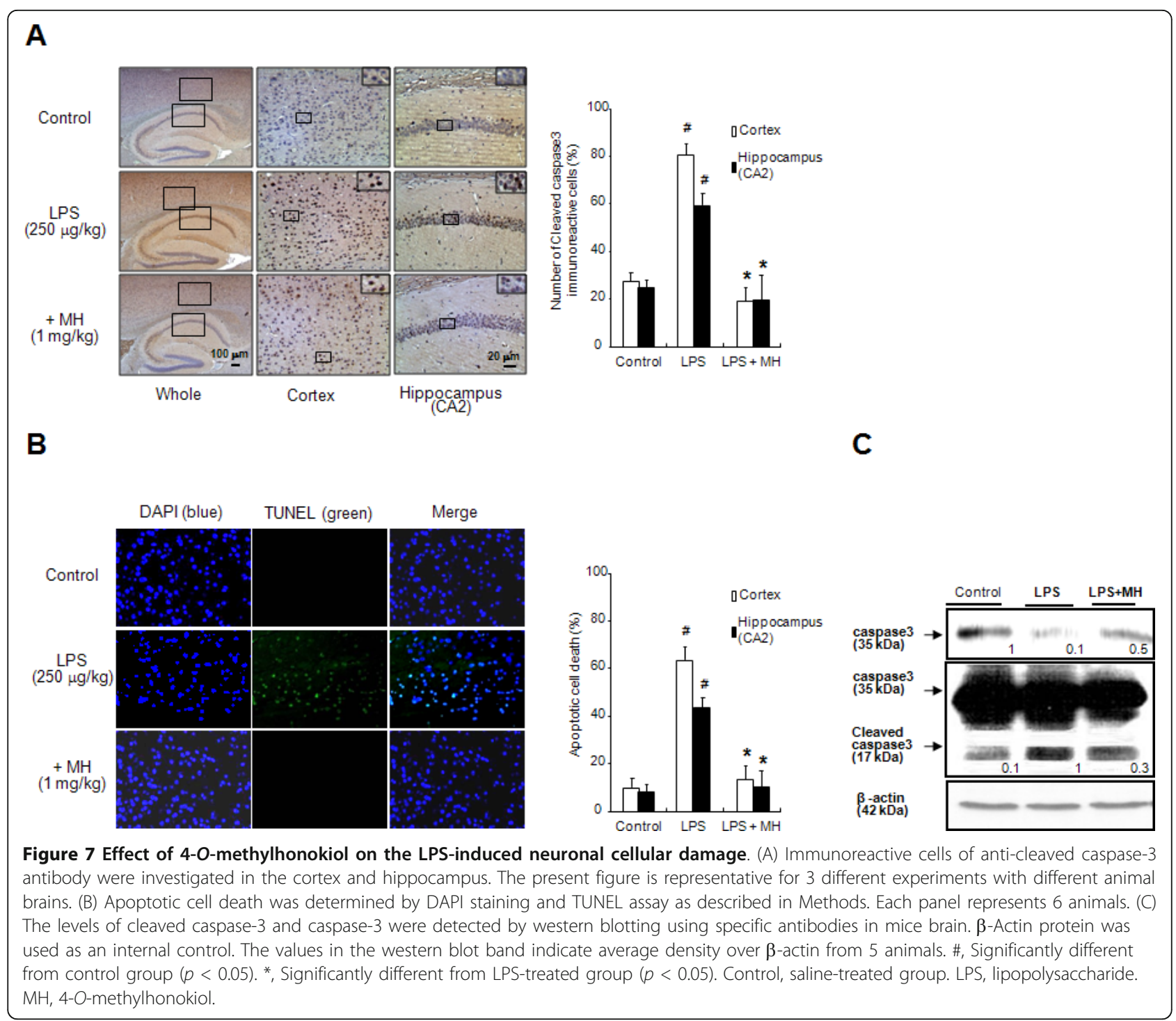

neuroinflammatory properties in LPS-induced in vivo and in vitro model, and ameliorated memory impairment. Accumulating epidemiological evidence has suggested that neuroinflammation may contribute to the occurrence and progression of $\mathrm{AD}[8,9,58-60]$, as brains of AD patients appear to display hallmarks of neuroinflammation, including marked astrogliosis, elevated release of proinflammatory mediators and cytokines, and microglial activation [61,62]. Recently, several researchers were reported that systemic administration of LPS induces release of proinflammatory mediators and cytokines such as TNF- $\alpha$, IL- $1 \beta$, iNOS, COX-2, cytosolic group IV phospholipase A2, 5-lipoxygenase and toll-like receptor-4 $[49,50,63]$, indicating that systemic inflammation induces neuroinflammation. Moreover, systemic administration of LPS has been reported to result in increased APP processing and intracellular accumulation of $A \beta$ as well as memory deficiency with concomitant increased neuroinflammation $[27,28,64,65]$. In particular, Jaeger et al. [51] reported that repeated systemic injections ( 3 times) of LPS increased $A \beta$ accumulation in the brain through increased influx of blood $A \beta$ contributed to alteration of LRP-1 in mice brain although it is different with our mechanism of amyloid deposition, and it supports our LPS-induced AD model. Administration of non-steroidal anti-inflammatory drugs (NSAIDs) could reduce the risk and delay the onset of $\mathrm{AD}[25,60,66]$. Thus, anti-inflammatory agents could decrease amyloidogenesis and memory deficiency via the prevention of neuroinflammation.

The results of our previous studies $[27,28]$ and the present one showed that inflammatory and amyloidogenic genes were concomitantly increased by treatment with LPS. However, 4-O-methylhonokiol has resulted in 


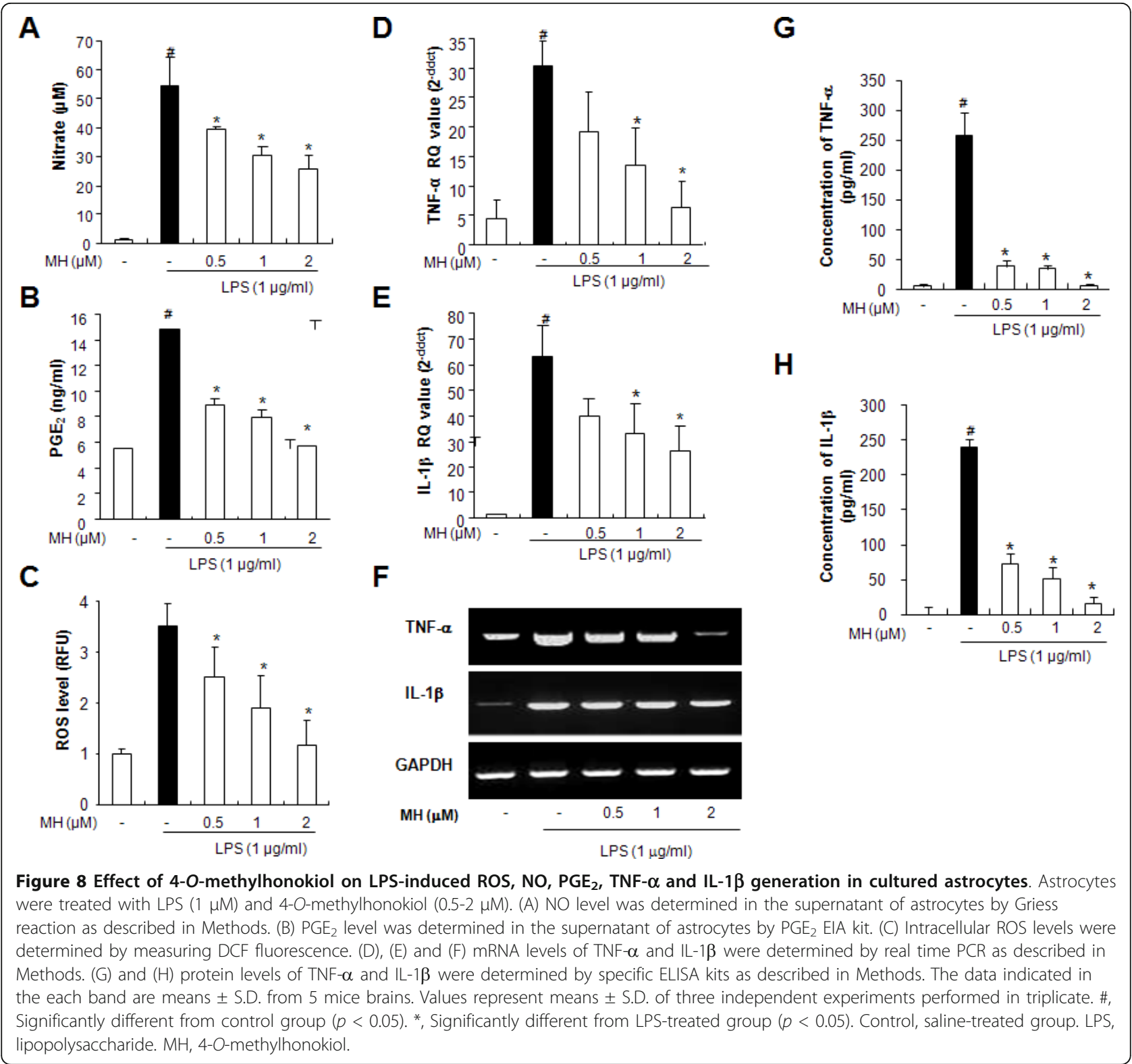

the inhibition of the expression of the NF- $\kappa \mathrm{B}$ and NF$\kappa \mathrm{B}$-mediated expression of inflammatory proteins; COX2 and iNOS as well as ROS, NO, PGE 2 , TNF- $\alpha$ and IL$1 \beta$ levels in the brain and in cultured astrocytes. These inhibitory effects are in agreement with the inhibitory effects on the expression of proteins involved in amyloidogenesis, such as BACE1 and C99, a product of BACE1. 4-O-methylhonokiol also inhibited the proteolytic cleavage of APP via the inhibition of $\beta$ - or $\gamma$-secretase activity, resulting in the reduction of $A \beta$ generation. Activation of astrocytes has been known to increase $\beta$ secretase activity, thereby increase $A \beta$ generation [67-69]. In fact, we found that GFAP (activation of astrocytes) was co-localized with $A \beta$, and this co- stimulation was increased by LPS, but was prevented by 4-O-methylhonokiol. BACE1 expression was detectable as early as the morphological features of reactive astrocytes. The astrocytic expression of BACE1 after induction of chronic gliosis was not only limited to experimental animals but also included astrocytes in close proximity to $\beta$-amyloid plaques in the brains of AD patients [70]. Thus, the present data indicated that the anti-inflammatory properties of 4-O-methylhononkiol could be associated with anti-amyloidogenesis.

It is not clear how 4-O-methylhonokiol concomitantly reduces neuroinflammation and amyloidogenesis. However, it is noteworthy that ROS and NO have been implicated in the activation of BACE1 expression as well 


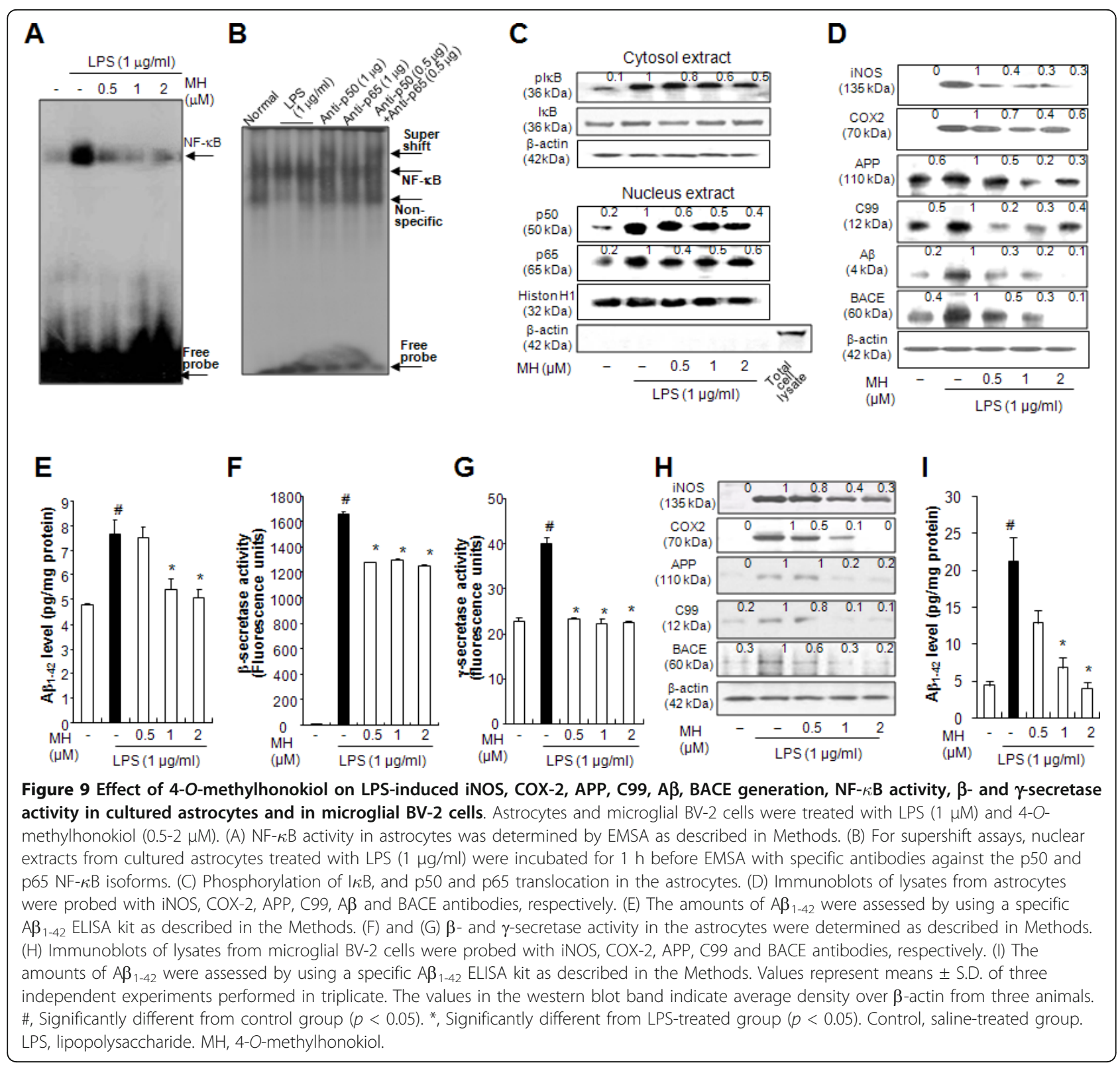

as in the activity of $\beta$ - and $\gamma$-secretases [71,72]. In a recent study, the role of ROS release by the mitochondrial electron chain in response to hypoxia was determined to foster amyloidogenic APP processing via the up-regulation of $\beta$-secretase activity [72]. Additionally, we previously found that compounds having antioxidant properties such as EGCG and L-theanine showed antineuroinflammatory responses and anti-amyloidogenesis activity via anti-oxidant mechanisms [27,73]. Anti-oxidants such as superoxide dismutase [74], $\alpha$-lipoic acid [75], S-nitrosoglutathione [76], curcumin and docosahexaenoic acid [77], also prevented cognitive deficits, oxidative damage and amyloidogenesis in AD models. Inflammatory reactions have also been known to directly regulate amyloidogenesis via the modification of $\beta$-secretase activity [78]. LPS-treated mice exhibited increases in both the levels of inflammatory products and amyloid formation as well as in secretases activity in the neurons of the mouse brain [64]. We also found that 4-O-methylhonokiol prevented the activation of astrocytes in culture or in the brain of AD-model mice such as $\mathrm{A} \beta$-injected or PS2 mutant transgenic mice [43,44,48]. Moreover, several anti-inflammatory agents have been reported to have anti-amyloidogenic effects. The administration of minocycline in 8-month-old 3xTg-AD mice was also shown to prevent cognitive deficits and to decrease insoluble $A \beta$ and soluble fibrils via the reduction of inflammatory agents such as GFAP, TNF- $\alpha$ and IL-6 [79]. Furthermore, 
ibuprofen was reported to reduce $A \beta_{1-42}$ production via the inhibition of $\gamma$-secretase [80] and the reduction of neuroinflammation via COX inhibition [81]. Ibuprofen also decreased $\beta$-secretase activity via inhibition of peroxisome proliferator-activated receptor gamma [82], cytokines, $\alpha-1$-antichymotrypsin [83] and the Rho cascade $[84,85]$. Thus, anti-oxidative and anti-inflammatory properties of 4-O-methylhonokiol could be significant for anti-amyloidogenesis.

The generation of $A \beta$ requires the proteolytic cleavage of APP by an aspartyl protease named BACE1 [86]. A number of transcriptional factors as well as posttranscriptional modifications and intracellular signaling molecule activation, regulate BACE1 expression in the brain [87]. The expression of endogenous BACE1 proteins in differentiated PC12 cells was decreased by the pharmacological inhibition of NF- $\kappa \mathrm{B}$ activation via (R)-flurbiprofen and by treatment with decoy oligonucleotides that were specific for the BACE1 protein promoter NF- $\kappa$ B site $[87,88]$. NF- $\kappa$ B has also been well documented in decreasing transcription factors regulating $\beta$-secretase in activated astrocytes $[89,90]$. The promoters of APP [91], presenilin and BACE1 [92] contain NF- $\kappa$ B sites, which derive transcription. Some NSAIDs such as flurbiprofen and indomethacin, which target NF- $\kappa \mathrm{B}$, have been shown to be effective at decreasing amyloid load in vitro and also in APP transgenic mice [93-95]. In addition, numerous factors were reported to inhibit amyloidogenesis via suppression of NF- $\kappa \mathrm{B}$ such as sorafenib [96], L-theanine [73], and tripchlorolide [97]. We previously found that activation of NF- $\kappa \mathrm{B}$ contributes to the increase in $\beta$-secretase in neuronal cells expressing mutant PS2 [44], and also demonstrated that EGCG, as a well known anti-oxidant and anti-inflammatory agent, inhibits $\beta$ - and $\gamma$-secretases activity via inhibition of NF$\kappa \mathrm{B}$ pathways in PS2 mice [42]. It was also illustrated that 4-O-methylhonokiol had an anti-inflammatory effect in LPS-induced RAW 264.7 cells via inhibition of NF- $\kappa$ B pathway activation [35]. In this study, 4-O-methylhonokiol inhibited dose-dependent LPS-induced activation of the NF- $\kappa \mathrm{B}$ pathway in astrocytes, and this inhibition of NF- $\kappa \mathrm{B}$ pathway resulted in a dose-dependent decrease in the nuclear translocation of the p50 and p65 subunits, and it also decreased phosphorylation of $\mathrm{I} \kappa \mathrm{B}$ in astrocytes. Thus, inactivation of NF- $\kappa \mathrm{B}$ signaling pathways in the control of $\beta$ - and $\gamma$-secretase by 4-O-methylhonokiol could be critical in the reduction of these secretases, and thus the inhibition of $A \beta$ generation.

We previously performed the pharmacokinetic study in ICR mice. We treated by direct compulsory oral administration $(10 \mathrm{mg} / \mathrm{kg})$. We found that oral treatment of 4-O-methylhonokiol rapidly disappears from the blood and is distributed into brain rapidly (less than $1 \mathrm{hr}$ after treatment) (unpublished data). The blood concentration of 4-O-methylhonokiol gets platue after 2 hr treatment which is similar level with the concentration by intravenous injection. The effective dose of blood may be about $20 \mathrm{ng} / \mathrm{ml}$. The tissue concentration pharmacokinetic profile showed that the 4-O-methylhonokiol could be accumulated into brain, and about 50$100 \mathrm{ng} / \mathrm{ml}$ may be effective dose in the brain. Moreover, oral administration of 4-O-methylhonokiol of as much as $80 \mathrm{mg} / \mathrm{kg}$ for 4 weeks did not cause weight loss or other toxicities in a repeated-dose toxicity study (unpublished data). 4-O-methylhonokiol was also evaluated as noncarcinogenic in rodents (data not shown). These data suggest that it could be safe and effective in a clinical application.

\section{Conclusion}

Our data show that 4-O-methylhonokiol has ameliorated LPS-induced memory deficiencies via the inhibition of $A \beta_{1-42}$ generation, by inactivating $\beta$ - and $\gamma$-secretases and astrocytes via the inactivation of NF- $\kappa \mathrm{B}$ pathways. This study therefore suggests that 4-O-methylhonokiol may be a useful agent for preventing the development or progression of $\mathrm{AD}$.

\section{Abbreviations}

Aß: Amyloid beta-peptide; AD: Alzheimer's disease; APP: Amyloid precursor protein; BACE1: $\beta$-secretase-1; DAPI: 4'-6-diamidino-2-phenylindole; DCF-DA: 2,7'-Dichlorofluorescein diacetate; DMEM: Dulbecco's modified Eagle's medium; EGCG: (-)-Epigallocatechin 3-gallate; ELISA: Enzyme-linked immunosorbent assay; EMSA: Electrophoretic mobility shift assay; FBS: Fetal bovine serum; GAPDH: Glyceraldehyde-3-phosphate dehydrogenase; GFAP: Glial fibrillary acidic protein; Iba1: Ionized calcium binding adaptor molecule 1; ICR: Imprinting control region; IL: Interleukin; i.p.: intraperitoneal; iNOS: Inducible nitric oxide synthase; LPS: Lipopolysaccharide; NF: Nuclear factor; NMR: Nuclear magnetic resonance; NO: Nitric oxide; NSAIDs: Nonsteroidal anti-inflammatory drugs; PBS: Phosphate-buffered saline; PCR: Polymerase chain reaction; $\mathrm{PGE}_{2}$ : Prostaglandin E2; ROS: Reactive oxygen species; SD: Standard deviation; TNF: Tumor necrosis factor; TUNEL: Terminal deoxynucleotidyl transferase-mediated dUTP-biotin nick end-labeling.

\section{Acknowledgements}

This work was supported by the National Research Foundation of Korea [NRF] grant funded by the Korea government [MEST] (MRC, 2010-0029480) and by a grant (No. A101836) of the Korean Health Technology R\&D Project, Ministry for Health, Welfare \& Family Affairs, Republic of Korea.

\section{Author details}

'College of Pharmacy, Chungbuk National University, 12, Gaeshin-dong Heungduk-gu, Cheongju, Chungbuk 361-763, Korea. ${ }^{2}$ Medical Research Center, Chungbuk National University, 12 Gaesin-dong, Heungduk-gu, Cheongju, Chungbuk 361-763, Korea. ${ }^{3}$ R\&D Center, Bioland Ltd., Songjeong, Byongchon, Cheonan-Si, Chungnam 330-863, Korea. ${ }^{4}$ College of Pharmacy, Gachon University of Medicine and Science, Incheon 406-799, Korea. ${ }^{5}$ Wonju College of Medicine, Yonsei University, 162 Ilsan-dong, Wonju-si, Ganwon-do 220-701, Korea. ${ }^{6}$ College of Veterinary Medicine and Research Institute of Veterinary Medicine (RIVM), Chungbuk National University, 12 Gaesin-dong, Heungduk-gu, Cheongju, Chungbuk 361-763, Korea. ${ }^{7}$ Department of Biotechnology and Bioinformatics, Chungbuk Provincial College of Science \& Technology, Okcheon, Chungbuk 373-807, Korea.

\section{Authors' contributions}

Hong JT designed the study. Lee YJ prepared the manuscript and performed experiments. Choi DY and Choi IS performed experiments. Kim 
$\mathrm{KH}$ and Kim YH isolated and characterized 4-O-methylhonokiol. Kim HM, Lee K, Cho WG, Jung JK, Han SB, Han JY, Nam SY, Yun YW and Oh KW discussed the study. All authors have read and approved the final version of this manuscript.

\section{Competing interests}

The authors declare that they have no competing interests.

Received: 7 October 2011 Accepted: 19 February 2012 Published: 19 February 2012

\section{References}

1. Blennow K, de Leon MJ, Zetterberg H: Alzheimer's disease. Lancet 2006, 368:387-403.

2. Ferri CP, Sousa R, Albanese E, Ribeiro WS, Honyashiki M: World Alzheimer Report 2009-Executive Summary.Edited by: Prince M, Jackson J. London: Alzheimer's Disease International; 2009:1-22.

3. Mattson MP, Maudsley S, Martin B: A neural signaling triumvirate that influences ageing and age-related disease: insulin/IGF-1, BDNF and serotonin. Ageing Res Rev 2004, 3:445-464

4. McGeer PL, Schulzer M, McGeer EG: Arthritis and anti-inflammatory agents as possible protective factors for Alzheimer's disease: a review of 17 epidemiologic studies. Neurology 1996, 47:425-432.

5. Quintanilla RA, Orellana DI, Gonzalez-Billault C, Maccioni RB: Interleukin-6 induces Alzheimer-type phosphorylation of tau protein by deregulating the cdk5/p35 pathway. Exp Cell Res 2004, 295:245-257.

6. Orellana DI, Quintanilla RA, Gonzalez-Billault C, Maccioni RB: Role of the JAKs/STATs pathway in the intracellular calcium changes induced by interleukin-6 in hippocampal neurons. Neurotox Res 2005, 8:295-304.

7. Orellana DI, Quintanilla RA, Maccioni RB: Neuroprotective effect of TNFalpha against the beta-amyloid neurotoxicity mediated by CDK5 kinase. Biochim Biophys Acta 2007, 1773:254-263.

8. Eikelenboom P, Bate C, Van Gool WA, Hoozemans JJ, Rozemuller JM, Veerhuis R, Williams A: Neuroinflammation in Alzheimer's disease and prion disease. Glia 2002, 40:232-239.

9. McGeer EG, McGeer PL: Inflammatory processes in Alzheimer's disease. Prog Neuropsychopharmacol Biol Psychiatry 2003, 27:741-749.

10. Guo JT, Yu J, Grass D, de Beer FC, Kindy MS: Inflammation-dependent cerebral deposition of serum amyloid a protein in a mouse model of amyloidosis. J Neurosci 2002, 22:5900-5909.

11. Simic G, Lucassen PJ, Krsnik Z, Kruslin B, Kostovic I, Winblad B, Bogdanovi $\mathrm{nNOS}$ expression in reactive astrocytes correlates with increased cell death related DNA damage in the hippocampus and entorhinal cortex in Alzheimer's disease. Exp Neurol 2000, 165:12-26.

12. Buxbaum JD, Oishi M, Chen HI, Pinkas-Kramarski R, Jaffe EA, Gandy SE, Greengard P: Cholinergic agonists and interleukin 1 regulate processing and secretion of the Alzheimer beta/A4 amyloid protein precursor. Proc Natl Acad Sci USA 1992, 89:10075-10078.

13. Hirose Y, Imai Y, Nakajima K, Takemoto N, Toya S, Kohsaka S: Glial conditioned medium alters the expression of amyloid precursor protein in SH-SY5Y neuroblastoma cells. Biochem Biophys Res Commun 1994, 198:504-509.

14. Blasko I, Marx F, Steiner E, Hartmann T, Grubeck-Loebenstein B: TNFalpha plus IFNgamma induce the production of Alzheimer beta-amyloid peptides and decrease the secretion of APPs. FASEB J 1999, 13:63-68.

15. Sastre M, Dewachter I, Landreth GE, Willson TM, Klockgether T, van Leuven F, Heneka MT: Nonsteroidal anti-inflammatory drugs and peroxisome proliferator-activated receptor-gamma agonists modulate immunostimulated processing of amyloid precursor protein through regulation of beta-secretase. J Neurosci 2003, 23:9796-9804.

16. Vassar R: The beta-secretase, BACE: a prime drug target for Alzheimer's disease. J Mol Neurosci 2001, 17:157-170.

17. Rezai-Zadeh K, Shytle D, Sun N, Mori T, Hou H, Jeanniton D, Ehrhart J, Townsend K, Zeng J, Morgan D, et al: Green tea epigallocatechin-3-gallate (EGCG) modulates amyloid precursor protein cleavage and reduces cerebral amyloidosis in Alzheimer transgenic mice. J Neurosci 2005, 25:8807-8814.

18. Obregon DF, Rezai-Zadeh K, Bai Y, Sun N, Hou H, Ehrhart J, Zeng J, Mori T, Arendash GW, Shytle $D$, et al: ADAM10 activation is required for green tea (-)-epigallocatechin-3-gallate-induced alpha-secretase cleavage of amyloid precursor protein. J Biol Chem 2006, 281:16419-16427.
19. McGeer $\mathrm{PL}$, Rogers J: Anti-inflammatory agents as a therapeutic approach to Alzheimer's disease. Neurology 1992, 42:447-449.

20. Shaw KN, Commins S, O'Mara SM: Lipopolysaccharide causes deficits in spatial learning in the watermaze but not in BDNF expression in the rat dentate gyrus. Behav Brain Res 2001, 124:47-54.

21. Sparkman NL, Martin LA, Calvert WS, Boehm GW: Effects of intraperitoneal lipopolysaccharide on Morris maze performance in year-old and 2month-old female C57BL/6J mice. Behav Brain Res 2005, 159:145-151.

22. Parnet $P$, Kelley KW, Bluthe RM, Dantzer R: Expression and regulation of interleukin-1 receptors in the brain. Role in cytokines-induced sickness behavior. J Neuroimmunol 2002, 125:5-14.

23. Zhang F, Qian L, Flood PM, Shi JS, Hong JS, Gao HM: Inhibition of IkappaB kinase-beta protects dopamine neurons against lipopolysaccharideinduced neurotoxicity. J Pharmacol Exp Ther 2010, 333:822-833.

24. Hang CH, Shi JX, Tian J, Li JS, Wu W, Yin HX: Effect of systemic LPS injection on cortical NF-kappaB activity and inflammatory response following traumatic brain injury in rats. Brain Res 2004, 1026:23-32.

25. Lee YJ, Han SB, Nam SY, Oh KW, Hong JT: Inflammation and Alzheimer's disease. Arch Pharm Res 2010, 33:1539-1556.

26. Wang L-Y, Niu Z-Z, Hu B-X, Wu J-m, Jiang X, Hu X-f, Huang W-h, Ouyang J, Yu L, Qiu X-Z: Long-term intraperitoneal injection of lipopolysaccharide induces high expression of Id2 in the brain of mice. Mol Biol Rep 2011, 38:4193-4196.

27. Lee YK, Yuk DY, Lee JW, Lee SY, Ha TY, Oh KW, Yun YP, Hong JT: (-)-Epigallocatechin-3-gallate prevents lipopolysaccharide-induced elevation of beta-amyloid generation and memory deficiency. Brain Res 2008, 1250:164-174.

28. Lee JW, Lee YK, Yuk DY, Choi DY, Ban SB, Oh KW, Hong JT: Neuroinflammation induced by lipopolysaccharide causes cognitive impairment through enhancement of beta-amyloid generation. $J$ Neuroinflammation 2008, 5:37.

29. Kuribara H, Kishi E, Hattori N, Okada M, Maruyama Y: The anxiolytic effect of two oriental herbal drugs in Japan attributed to honokiol from magnolia bark. J Pharm Pharmacol 2000, 52:1425-1429.

30. Li Y, Xu C, Zhang Q, Liu JY, Tan RX: In vitro anti-Helicobacter pylori action of 30 Chinese herbal medicines used to treat ulcer diseases. $J$ Ethnopharmacol 2005, 98:329-333.

31. Ock J, Han HS, Hong SH, Lee SY, Han YM, Kwon BM, Suk K: Obovatol attenuates microglia-mediated neuroinflammation by modulating redox regulation. Br J Pharmacol 2010, 159:1646-1662.

32. Lin YR, Chen $\mathrm{HH}$, Ko CH, Chan MH: Effects of honokiol and magnolol on acute and inflammatory pain models in mice. Life Sci 2007, 81:1071-1078.

33. Munroe ME, Arbiser JL, Bishop GA: Honokiol, a natural plant product, inhibits inflammatory signals and alleviates inflammatory arthritis. J Immunol 2007, 179:753-763.

34. Chen YH, Lin SJ, Chen YL, Liu PL, Chen JW: Anti-inflammatory effects of different drugs/agents with antioxidant property on endothelial expression of adhesion molecules. Cardiovasc Hematol Disord Drug Targets 2006, 6:279-304

35. Zhou HY, Shin EM, Guo LY, Youn UJ, Bae K, Kang SS, Zou LB, Kim YS: Antiinflammatory activity of 4-methoxyhonokiol is a function of the inhibition of iNOS and COX-2 expression in RAW 264.7 macrophages via NF-kappaB, JNK and p38 MAPK inactivation. Eur J Pharmacol 2008, 586:340-349.

36. Lin YR, Chen $\mathrm{HH}, \mathrm{Ko} \mathrm{CH}$, Chan MH: Neuroprotective activity of honokiol and magnolol in cerebellar granule cell damage. Eur J Pharmacol 2006, 537:64-69.

37. Bajpai VK, Yoon Jl, Kang SC: Antioxidant and antidermatophytic activities of essential oil and extracts of Magnolia liliflora Desr. Food Chem Toxicol 2009, 47:2606-2612.

38. Dikalov S, Losik T, Arbiser JL: Honokiol is a potent scavenger of superoxide and peroxyl radicals. Biochem Pharmacol 2008, 76:589-596.

39. Chen YH, Lin FY, Liu PL, Huang YT, Chiu JH, Chang YC, Man KM, Hong CY, Ho YY, Lai MT: Antioxidative and hepatoprotective effects of magnolol on acetaminophen-induced liver damage in rats. Arch Pharm Res 2009, 32:221-228.

40. Oh JH, Kang LL, Ban JO, Kim YH, Kim KH, Han SB, Hong JT: Antiinflammatory effect of 4-O-methylhonokiol, a novel compound isolated from Magnolia officinalis through inhibition of NF-kappaB. Chem Biol Interact 2009, 180:506-514. 
41. Lee YK, Choi IS, Kim YH, Kim KH, Nam SY, Yun YW, Lee MS, Oh KW, Hong JT: Neurite Outgrowth Effect of 4-O-methylhonokiol by Induction of Neurotrophic Factors Through ERK Activation. Neurochem Res 2009, 34:2251-2260.

42. Lee JW, Lee YK, Ban JO, Ha TY, Yun YP, Han SB, Oh KW, Hong JT: Green tea (-)-epigallocatechin-3-gallate inhibits beta-amyloid-induced cognitive dysfunction through modification of secretase activity via inhibition of ERK and NF-kappaB pathways in mice. J Nutr 2009, 139:1987-1993.

43. Lee JW, Lee YK, Lee BJ, Nam SY, Lee SI, Kim YH, Kim KH, Oh KW, Hong JT: Inhibitory effect of ethanol extract of Magnolia officinalis and 4-Omethylhonokiol on memory impairment and neuronal toxicity induced by beta-amyloid. Pharmacol Biochem Behav 2010, 95:31-40.

44. Lee YJ, Choi IS, Park MH, Lee YM, Song JK, Kim YH, Kim KH, Hwang DY, Jeong JH, Yun YP, et al: 4-O-Methylhonokiol attenuates memory impairment in presenilin 2 mutant mice through reduction of oxidative damage and inactivation of astrocytes and the ERK pathway. Free Radic Biol Med 2011, 50:66-77.

45. Lee YK, Yuk DY, Kim TI, Kim YH, Kim KT, Kim KH, Lee BJ, Nam SY, Hong JT: Protective effect of the ethanol extract of Magnolia officinalis and 4-Omethylhonokiol on scopolamine-induced memory impairment and the inhibition of acetylcholinesterase activity. J Nat Med 2009, 63:274-282.

46. Rao KV, Davis TL: Constituents of Magnolia grandiflora i: mono-Omethylhonokiol. Planta Med 1982, 45:57-59.

47. Yahara S, Nishiyori T, Kohda T, Nohara T, Nishioka I: Isolation and Characterization of Phenolic Compounds from Magnoliae Cortex Produced in China. Chemistry Pharmacology Bulletin 1991, 39:2024-2036.

48. Lee YK, Choi IS, Ban JO, Lee HJ, Lee US, Han SB, Jung JK, Kim YH, Kim KH, Oh KW, Hong JT: 4-O-methylhonokiol attenuated beta-amyloid-induced memory impairment through reduction of oxidative damages via inactivation of p38 MAP kinase. J Nutr Biochem 2011, 22:476-486.

49. Erickson MA, Banks WA: Cytokine and chemokine responses in serum and brain after single and repeated injections of lipopolysaccharide: Multiplex quantification with path analysis. Brain Behav Immun 2011, 25:1637-1648.

50. Czapski GA, Gajkowska B, Strosznajder JB: Systemic administration of lipopolysaccharide induces molecular and morphological alterations in the hippocampus. Brain Res 2010, 1356:85-94.

51. Jaeger LB, Dohgu S, Sultana R, Lynch JL, Owen JB, Erickson MA, Shah GN, Price TO, Fleegal-Demotta MA, Butterfiled DA, Banks WA: Lipopolysaccharide alters the blood-brain barrier transport of amyloid beta protein: a mechanism for inflammation in the progression of Alzheimer's disease. Brain Behav Immun 2009, 23:507-517.

52. Morris R: Developments of a water-maze procedure for studying spatial learning in the rat. J Neurosci Methods 1984, 11:47-60.

53. Park KS, Lee RD, Kang SK, Han SY, Park KL, Yang KH, Song YS, Park HJ, Lee YM, Yun YP, et al: Neuronal differentiation of embryonic midbrain cells by upregulation of peroxisome proliferator-activated receptorgamma via the JNK-dependent pathway. Exp Cell Res 2004, 297:424-433.

54. Lee SM, Nguyen TH, Park MH, Kim KS, Cho KJ, Moon DC, Kim HY, Yoon DY, Hong JT: EPO receptor-mediated ERK kinase and NF-kappaB activation in erythropoietin-promoted differentiation of astrocytes. Biochem Biophys Res Commun 2004, 320:1087-1095.

55. Szczepanik AM, Ringheim GE: IL-10 and glucocorticoids inhibit Abeta(142)- and lipopolysaccharide-induced pro-inflammatory cytokine and chemokine induction in the central nervous system. J Alzheimers Dis 2003, 5:105-117.

56. Wilcock DM, Gordon MN, Morgan D: Quantification of cerebral amyloid angiopathy and parenchymal amyloid plaques with Congo red histochemical stain. Nat Protoc 2006, 1:1591-1595.

57. Nguyen HN, Lee MS, Hwang DY, Kim YK, Yoon do Y, Lee JW, Yun YP, Lee MK, Oh KW, Hong JT: Mutant presenilin 2 increased oxidative stress and p53 expression in neuronal cells. Biochem Biophys Res Commun 2007, 357:174-180.

58. Akiyama H, Barger S, Barnum S, Bradt B, Bauer J, Cole GM, Cooper NR, Eikelenboom P, Emmerling M, Fiebich BL, et al: Inflammation and Alzheimer's disease. Neurobiol Aging 2000, 21:383-421.

59. Giovannini MG, Scali C, Prosperi C, Bellucci A, Vannucchi MG, Rosi S, Pepeu G, Casamenti F: Beta-amyloid-induced inflammation and cholinergic hypofunction in the rat brain in vivo: involvement of the p38MAPK pathway. Neurobiol Dis 2002, 11:257-274.

60. Veerhuis R: Histological and direct evidence for the role of complement in the neuroinflammation of AD. Curr Alzheimer Res 2011, 8:34-58.
61. Butterfield DA, Drake J, Pocernich C, Castegna A: Evidence of oxidative damage in Alzheimer's disease brain: central role for amyloid betapeptide. Trends Mol Med 2001, 7:548-554.

62. Morley JE, Farr SA, Kumar VB, Banks WA: Alzheimer's disease through the eye of a mouse. Acceptance lecture for the 2001 Gayle A. Olson and Richard D. Olson prize. Peptides 2002, 23:589-599.

63. Mouton PR, Kelley-Bell B, Tweedie D, Spangler EL, Perez E, Carlson OD, Short RG, Decabo R, Chang J, Ingram DK, et al: The effects of age and lipopolysaccharide (LPS)-mediated peripheral inflammation on numbers of central catecholaminergic neurons. Neurobiol Aging 2012, 33:423 e427-436.

64. Sheng JG, Bora SH, Xu G, Borchelt DR, Price DL, Koliatsos VE: Lipopolysaccharide-induced-neuroinflammation increases intracellular accumulation of amyloid precursor protein and amyloid beta peptide in APPswe transgenic mice. Neurobiol Dis 2003, 14:133-145.

65. Michelucci A, Heurtaux T, Grandbarbe L, Morga E, Heuschling P: Characterization of the microglial phenotype under specific proinflammatory and anti-inflammatory conditions: Effects of oligomeric and fibrillar amyloid-beta. J Neuroimmunol 2009, 210:3-12.

66. Heneka MT, Kummer MP, Weggen S, Bulic B, Multhaup G, Munter L, Hull M, Pflanzner T, Pietrzik CU: Molecular mechanisms and therapeutic application of NSAIDs and derived compounds in Alzheimer's disease. Curr Alzheimer Res 2011, 8:115-131.

67. Gunasingh MJ, Philip JE, Ashok BS, Kirubagaran R, Jebaraj WC, Davis GD, Vignesh S, Dhandayuthapani S, Jayakumar R: Melatonin prevents amyloid protofibrillar induced oxidative imbalance and biogenic amine catabolism. Life Sci 2008, 83:96-102.

68. Schubert D, Soucek T, Blouw B: The induction of HIF-1 reduces astrocyte activation by amyloid beta peptide. Eur J Neurosci 2009, 29:1323-1334.

69. Cho HJ, Kim SK, Jin SM, Hwang EM, Kim YS, Huh K, Mook-Jung I: IFNgamma-induced BACE1 expression is mediated by activation of JAK2 and ERK1/2 signaling pathways and direct binding of STAT1 to BACE1 promoter in astrocytes. Glia 2007, 55:253-262.

70. Hartlage-Rubsamen M, Zeitschel U, Apelt J, Gartner U, Franke H, Stahl T, Gunther A, Schliebs R, Penkowa M, Bigl V, Rossner S: Astrocytic expression of the Alzheimer's disease beta-secretase (BACE1) is stimulusdependent. Glia 2003, 41:169-179.

71. Sheng B, Gong K, Niu Y, Liu L, Yan Y, Lu G, Zhang L, Hu M, Zhao N, Zhang $X$, et al: Inhibition of gamma-secretase activity reduces Abeta production, reduces oxidative stress, increases mitochondrial activity and leads to reduced vulnerability to apoptosis: Implications for the treatment of Alzheimer's disease. Free Radic Biol Med 2009, 46:1362-1375.

72. Guglielmotto M, Tamagno E, Danni O: Oxidative stress and hypoxia contribute to Alzheimer's disease pathogenesis: two sides of the same coin. ScientificWorldJournal 2009, 9:781-791.

73. Kim TI, Lee YK, Park SG, Choi IS, Ban JO, Park HK, Nam SY, Yun YW, Han SB, Oh KW, Hong JT: I-Theanine, an amino acid in green tea, attenuates beta-amyloid-induced cognitive dysfunction and neurotoxicity: reduction in oxidative damage and inactivation of ERK/p38 kinase and NF-kappaB pathways. Free Radic Biol Med 2009, 47:1601-1610.

74. Massaad CA, Washington TM, Pautler RG, Klann E: Overexpression of SOD2 reduces hippocampal superoxide and prevents memory deficits in a mouse model of Alzheimer's disease. Proc Natl Acad Sci USA 2009, 106:13576-13581.

75. Quinn JF, Bussiere JR, Hammond RS, Montine TJ, Henson E, Jones RE, Stackman RW Jr: Chronic dietary alpha-lipoic acid reduces deficits in hippocampal memory of aged Tg2576 mice. Neurobiol Aging 2007, 28:213-225.

76. Ju TC, Chen SD, Liu CC, Yang DI: Protective effects of S-nitrosoglutathione against amyloid beta-peptide neurotoxicity. Free Radic Biol Med 2005, 38:938-949.

77. Cole GM, Lim GP, Yang F, Teter B, Begum A, Ma Q, Harris-White ME, Frautschy SA: Prevention of Alzheimer's disease: Omega-3 fatty acid and phenolic anti-oxidant interventions. Neurobiol Aging 2005, 26(Suppl 1):133-136.

78. Garcia-Matas S, de Vera N, Aznar AO, Marimon JM, Adell A, Planas AM, Cristofol R, Sanfeliu C: In vitro and in vivo activation of astrocytes by amyloid-beta is potentiated by pro-oxidant agents. J Alzheimers Dis 2010, 20:229-245.

79. Parachikova A, Vasilevko V, Cribbs DH, LaFerla FM, Green KN: Reductions in amyloid-beta-derived neuroinflammation, with minocycline, restore 
cognition but do not significantly affect tau hyperphosphorylation. $J$ Alzheimers Dis 2010, 21:527-542.

80. Weggen S, Eriksen JL, Das P, Sagi SA, Wang R, Pietrzik CU, Findlay KA, Smith TE, Murphy MP, Bulter T, et al: A subset of NSAIDs lower amyloidogenic Abeta42 independently of cyclooxygenase activity. Nature 2001, 414:212-216.

81. Vane J: The mechanism of action of anti-inflammatory drugs. Int J Clin Pract Suppl 2003, 135:2.

82. Sastre M, Dewachter I, Rossner $\mathrm{S}$, Bogdanovic $N$, Rosen $E$, Borghgraef $P$, Evert BO, Dumitrescu-Ozimek L, Thal DR, Landreth G, et al: Nonsteroidal anti-inflammatory drugs repress beta-secretase gene promoter activity by the activation of PPARgamma. Proc Natl Acad Sci USA 2006, 103:443-448.

83. Morihara T, Teter B, Yang F, Lim GP, Boudinot S, Boudinot FD, Frautschy SA, Cole GM: Ibuprofen suppresses interleukin-1 beta induction of proamyloidogenic alpha1-antichymotrypsin to ameliorate beta-amyloid (Abeta) pathology in Alzheimer's models. Neuropsychopharmacology 2005, 30:1111-1120.

84. Zhou Y, Su Y, Li B, Liu F, Ryder JW, Wu X, Gonzalez-DeWhitt PA, Gelfanova V, Hale JE, May PC, et al: Nonsteroidal anti-inflammatory drugs can lower amyloidogenic Abeta42 by inhibiting Rho. Science 2003, 302:1215-1217.

85. Wilkinson BL, Cramer PE, Varvel NH, Reed-Geaghan E, Jiang Q, Szabo A, Herrup K, Lamb BT, Landreth GE: Ibuprofen attenuates oxidative damage through NOX2 inhibition in Alzheimer's disease. Neurobiol Aging 2012, 33:197 e121-132.

86. von Arnim CA, Spoelgen R, Peltan ID, Deng M, Courchesne S, Koker M, Matsui T, Kowa H, Lichtenthaler SF, Irizarry MC, Hyman BT: GGA1 acts as a spatial switch altering amyloid precursor protein trafficking and processing. J Neurosci 2006, 26:9913-9922.

87. Rossner S, Sastre M, Bourne K, Lichtenthaler SF: Transcriptional and translational regulation of BACE1 expression-implications for Alzheimer's disease. Prog Neurobiol 2006, 79:95-111.

88. Rossner S: New players in old amyloid precursor protein-processing pathways. Int J Dev Neurosci 2004, 22:467-474.

89. Hsieh $\mathrm{HL}$, Wang HH, Wu CY, Yang CM: Reactive Oxygen SpeciesDependent c-Fos/Activator Protein 1 Induction Upregulates Heme Oxygenase-1 Expression by Bradykinin in Brain Astrocytes. Antioxid Redox Signal 2010, 13:1829-1844.

90. Marcus JS, Karackattu SL, Fleegal MA, Sumners C: Cytokine-stimulated inducible nitric oxide synthase expression in astroglia: role of Erk mitogen-activated protein kinase and NF-kappaB. Glia 2003, 41:152-160.

91. Grilli M, Ribola M, Alberici A, Valerio A, Memo M, Spano P: Identification and characterization of a kappa $\mathrm{B} /$ Rel binding site in the regulatory region of the amyloid precursor protein gene. J Biol Chem 1995, 270:26774-26777.

92. Bourne KZ, Ferrari DC, Lange-Dohna C, Rossner S, Wood TG, Perez-Polo JR: Differential regulation of BACE1 promoter activity by nuclear factorkappaB in neurons and glia upon exposure to beta-amyloid peptides. J Neurosci Res 2007, 85:1194-1204.

93. Eriksen JL, Sagi SA, Smith TE, Weggen S, Das P, McLendon DC, Ozols W, Jessing KW, Zavitz KH, Koo EH, Golde TE: NSAIDs and enantiomers of flurbiprofen target gamma-secretase and lower Abeta 42 in vivo. J Clin Invest 2003, 112:440-449.

94. Sung $\mathrm{S}$, Yang H, Uryu K, Lee EB, Zhao L, Shineman D, Trojanowski JQ Lee VM, Pratico D: Modulation of nuclear factor-kappa B activity by indomethacin influences $A$ beta levels but not $A$ beta precursor protein metabolism in a model of Alzheimer's disease. Am J Pathol 2004, 165:2197-2206.

95. Kukar T, Prescott S, Eriksen JL, Holloway V, Murphy MP, Koo EH, Golde TE, Nicolle MM: Chronic administration of R-flurbiprofen attenuates learning impairments in transgenic amyloid precursor protein mice. BMC Neuros $C i$ 2007, 8:54

96. Echeverria V, Burgess S, Gamble-George J, Zeitlin R, Lin X, Cao C, Arendash GW: Sorafenib inhibits nuclear factor kappa B, decreases inducible nitric oxide synthase and cyclooxygenase-2 expression, and restores working memory in APPswe mice. Neuroscience 2009, 162:1220-1231.

97. Pan XD, Chen XC, Zhu YG, Chen LM, Zhang J, Huang TW, Ye QY, Huang HP: Tripchlorolide protects neuronal cells from microglia- mediated beta-amyloid neurotoxicity through inhibiting NF-kappaB and JNK signaling. Glia 2009, 57:1227-1238.

doi:10.1186/1742-2094-9-35

Cite this article as: Lee et al:: Inhibitory effect of 4-O-methylhonokiol on lipopolysaccharide-induced neuroinflammation, amyloidogenesis and memory impairment via inhibition of nuclear factor-kappaB in vitro and in vivo models. Journal of Neuroinflammation 2012 9:35.

\section{Submit your next manuscript to BioMed Central and take full advantage of:}

- Convenient online submission

- Thorough peer review

- No space constraints or color figure charges

- Immediate publication on acceptance

- Inclusion in PubMed, CAS, Scopus and Google Scholar

- Research which is freely available for redistribution 